\title{
Carbapenemases: Transforming Acinetobacter baumannii into a Yet More Dangerous Menace
}

\author{
Maria Soledad Ramirez ${ }^{1}$, Robert A. Bonomo ${ }^{2,3,4}$ and Marcelo E. Tolmasky ${ }^{1, * \mathbb{D}}$ \\ 1 Center for Applied Biotechnology Studies, Department of Biological Science, California State University \\ Fullerton, Fullerton, CA 92831, USA; msramirez@fullerton.edu \\ 2 Medical Service and GRECC, Louis Stokes Cleveland Department of Veterans Affairs Medical Center, \\ Cleveland, OH 44106, USA; robert.bonomo@va.gov \\ 3 Departments of Medicine, Pharmacology, Molecular Biology and Microbiology, Biochemistry, Proteomics \\ and Bioinformatics; Case Western Reserve University School of Medicine, Cleveland, OH 44106, USA \\ 4 WRU-Cleveland VAMC Center for Antimicrobial Resistance and Epidemiology (Case VA CARES), \\ Cleveland, $\mathrm{OH} 44106$, USA \\ * Correspondence: mtolmasky@fullerton.edu; Tel.: +657-278-5263
}

Received: 22 April 2020; Accepted: 29 April 2020; Published: 6 May 2020

\begin{abstract}
Acinetobacter baumannii is a common cause of serious nosocomial infections. Although community-acquired infections are observed, the vast majority occur in people with preexisting comorbidities. A. baumannii emerged as a problematic pathogen in the 1980s when an increase in virulence, difficulty in treatment due to drug resistance, and opportunities for infection turned it into one of the most important threats to human health. Some of the clinical manifestations of A. baumannii nosocomial infection are pneumonia; bloodstream infections; lower respiratory tract, urinary tract, and wound infections; burn infections; skin and soft tissue infections (including necrotizing fasciitis); meningitis; osteomyelitis; and endocarditis. A. baumannii has an extraordinary genetic plasticity that results in a high capacity to acquire antimicrobial resistance traits. In particular, acquisition of resistance to carbapenems, which are among the antimicrobials of last resort for treatment of multidrug infections, is increasing among $A$. baumannii strains compounding the problem of nosocomial infections caused by this pathogen. It is not uncommon to find multidrug-resistant (MDR, resistance to at least three classes of antimicrobials), extensively drug-resistant (XDR, MDR plus resistance to carbapenems), and pan-drug-resistant (PDR, XDR plus resistance to polymyxins) nosocomial isolates that are hard to treat with the currently available drugs. In this article we review the acquired resistance to carbapenems by A. baumannii. We describe the enzymes within the OXA, NDM, VIM, IMP, and KPC groups of carbapenemases and the coding genes found in A. baumannii clinical isolates.
\end{abstract}

Keywords: $\beta$-lactam; $\beta$-lactamase; antibiotic resistance; plasmid; ESKAPE; Acinetobacter

\section{A Brief Summary of Acinetobacter baumannii as a Pathogen}

Acinetobacter spp., a Gram-negative coccobacillus found in virtually all environments [1,2], used to be viewed as a "low-virulence" opportunistic pathogen of negligible significance. Despite signals about the potential this group of bacteria had as a nosocomial pathogen [3-6], its importance remained unappreciated until the mid-1990s [7]. Later, a better appreciation of the impact of Acinetobacter occurred after an increase in the understanding of its epidemiology identified it as the etiology of numerous hospital infections. In addition, an increase in virulence, difficulty of treatment due to drug resistance, and opportunities for infection, made this pathogen one of the most important threats 
to human health $[8,9]$. The spread and prevalence of $A$. baumannii in health care institutions was helped by its ability to withstand dry as well as humid environments, its resistance to disinfectants and antibiotics, and its biofilm-forming property that leads to colonization of inert surfaces and medical devices [10-13]. Taxonomy of the genus Acinetobacter has been complex, in part, due to the high genetic variability found among its members $[1,11]$.

A. baumannii, the most common cause of nosocomial infections caused by Acinetobacter, is part of what is known as the Acinetobacter calcoaceticus-baumannii complex, a group of bacteria that also includes Acinetobacter pittii, Acinetobacter nosocomialis, and Acinetobacter calcoaceticus [14]. A. baumannii is characterized by being catalase-positive, oxidase-negative, nonfermenting, and nonpigmented (although a pigmented strain has been recently described [15]). Although it was thought to be nonmotile, that property has been disputed by newer reports [10]. A. baumannii infections are almost exclusively nosocomial [10,11], but community-acquired cases have been reported [10,11,16-19]. However, the vast majority of community-acquired infections occur in people with preexisting comorbidities $[10,20,21]$. The most common clinical manifestation of A. baumannii nosocomial infection is pneumonia, which has been widely reported to increase patient mortality [2,22,23]. However, some reports still dispute this fact [24]. A vast majority of these infections occur in patients undergoing mechanical ventilation in intensive care units [25]. A. baumannii is also responsible for bloodstream infections mainly originating from intravascular devices $[10,26,27]$. The mortality rates of bloodstream infections caused by this bacterium range between $30 \%$ and $52 \%$ [26,27]. Other sources of $A$. baumannii bloodstream infections are lower respiratory tract, urinary tract, and wound infections [10]. Other manifestations caused by this bacterium include, but are not limited to, burn infections, skin and soft tissue infections (including necrotizing fasciitis), meningitis, osteomyelitis, and endocarditis [28-36].

A. baumannii has an extraordinary capacity to attach and survive on abiotic surfaces from non-medical objects like linen or door handles to medical equipment like catheters or respirators [37-40]. This property permits this bacterium to survive in health care environments despite the highly desiccated and starvation conditions that would kill other Gram-negatives [41-44]. As a consequence, A. baumannii is transmitted through contact with inanimate objects, making it a constant threat to immunosuppressed and weakened patients. The ability to attach to abiotic surfaces and to resist desiccation, together with the usual multidrug and disinfectant resistance exhibited by A. baumannii, are the major factors behind the success of this bacterium as a nosocomial pathogen [21,45-50].

In the past couple of decades, A. baumannii was studied intensely and, as a result, some virulence factors were identified and characterized [10,20,51-53]. Resistance to complement-mediated killing in the vast majority of A. baumannii clinical isolates is due to a capsular polysaccharide, of which numerous types are identified [54-58]. As it is the case for other bacteria [59-62], the synthesis of the capsular polysaccharide occurs through the undecaprenol-linked glycan pathway (the Wzx/Wzy-dependent pathway) [63-66]. An additional exopolysaccharide, poly- $\beta-(1-6)-N$-acetylglucosamine, is biosynthesized through the synthase-dependent pathway, i.e., a single synthase protein is responsible for the polymerization and the translocation process $[65,67]$. This polymer seems to play a role in efficient $A$. baumannii biofilm development [68].

Another carbohydrate-containing macromolecule, the lipooligosaccharide, so named because the antigen-O characteristic of lipopolysaccharides is absent in this bacterium [69,70], plays a role in resistance to colistin, an antibiotic that despite its toxicity is used as a last recourse against infection [70]. Resistance occurs through modifications in the chemistry or total loss of the lipooligosaccharide lipid A [71-74]. Membrane-associated protein O-glycosylation has been associated to virulence and biofilm formation in A. baumannii $[64,75]$. O-linked glycosylation of membrane proteins shares the initial steps of the capsular polysaccharide biosynthesis [64]. The role in A. baumannii virulence played by pili is less clear. Evidence that type IV pili play a fundamental role in the virulence of this pathogen [70] is not available. Its synthesis has been recently associated to the presence of thioredoxin-A [76]. 
Another kind of pili, the chaperone-usher pili may play a role in biofilm formation and infection $[49,70]$. The Type 2 secretion systems are associated to pathogenesis or antibiotic resistance [77,78]. Information on the involvement of the Type 6 secretion system is controversial [79-81].

Another group of potential A. baumannii virulence factors are those systems that facilitate efficient uptake of micronutrients [82-90]. A paradigmatic example of these virulence factors are the iron uptake systems [91,92] that bacteria evolved in response to the host's sequestration of iron, a group of non-specific systems of defense against bacterial infection. Despite its abundance, iron is poorly available in the host organism because it is complexed to ferritin in intracellular compartments or tightly bound to high-affinity iron-binding proteins like serum transferrin and lactoferrin [3,91-96]. To cause infection, bacteria must overcome this hurdle. Numerous iron acquisition systems were found in A. baumannii, and each strain possesses more than one of them. One of the systems facilitates transport of ferrous iron, known as Feo, consisting of three genes, $f e o A B C$, coding for a transmembrane (FeoB) and two hydrophilic cytoplasmic (FeoA and FeoC) proteins $[88,97,98]$. Two systems mediate the use of heme as source of iron, the hem $O$ and hem $T$ clusters [85,88,99-101]. Finally, three siderophore-mediated iron uptake systems have been identified to date. The acinetobactin system was the first to be discovered; it has been thoroughly studied, and it was shown to be critical for virulence $[87,102,103]$. Acinetobactin is closely related to anguibactin, another siderophore that was associated to virulence in Vibrio anguillarum [104-106]. The other two systems are those that utilize the siderophores fimsbactins (A-F) or baumannoferrins (A and B) $[89,107,108]$. Exhaustive and detailed descriptions of A. baumannii virulence factors can be found in recent excellent articles $[10,20,51,53,70,78,85,109-111]$. Other confirmed or proposed virulence factors include the phospholipases and elastase [112,113], the surface autotransporter Ata [114], the formation of outer membrane vesicles [115,116], survival factors such as serum resistance [42,117-121], and others [57,122-126].

Virulence of $A$. baumannii is enhanced in patients with predisposing factors such as diabetes, cancer, obstructive pulmonary disorders, immunocompromising diseases or treatment, and others [10,20,21]. Chronic alcoholism is also a risk factor for A. baumannii infection. Despite the rarity of community-acquired A. baumannii infection in the healthy population, this bacterium is a common etiologic agent of community-acquired pneumonia in individuals with a history of alcoholism [18]. Alcohol abuse causes a series of disturbances in the immune response, such as alteration of the monocytes function in presenting antigens to T-cells, alteration of the levels of cytokines and natural killer cells, as well as impairment of B-cells [127-131]. The detrimental effects of alcohol abuse on the immune system were shown to be a factor in the increased morbidity and mortality of $A$. baumannii [132].

Further studies on the alcohol-related A. baumannii-enhanced virulence showed elevated expression of 49 genes involved in multiple cellular functions after exposure to ethanol [125]. This study concluded that the effect of ethanol on virulence of $A$. baumannii involves numerous factors including the stress response [125]. Another study concluded that ethanol not only induces expression of certain genes, but also results in repression of others [126]. Some of the effects of ethanol described in this article include increased lipid and carbohydrate anabolism, enhanced biofilm formation, and decreased motility on semi-solid surfaces [126]. The presence of ethanol also induced the acidification of bacterial cultures and the production of indole-3-acetic acid. In summary, alcohol causes changes in the human body predisposing it for infection and induces changes that enhance or decrease expression of multiple bacterial functions that result in higher pathogenicity [125,126,132-134].

A property that turned A. baumannii into the human health threat that it has become is the resistance to multiple antibiotics exhibited by most clinical strains that complicate treatment [8]. In particular, resistance to carbapenems (Figure 1), which are among the antimicrobials of last resort for treatment of multidrug-resistant infections, is increasing among A. baumannii strains compounding the problem of nosocomial infections caused by this pathogen $[9,135]$. This is the reason why in the recent CDC's 2019 Antibiotic Resistance Threats Report, Carbapenem-resistant A. baumannii (CRAB) is listed as an "Urgent" threat [8]. Considering the importance of this urgent threat, in this review, we focus on carbapenemase-mediated resistance to carbapenems in A. baumannii. 


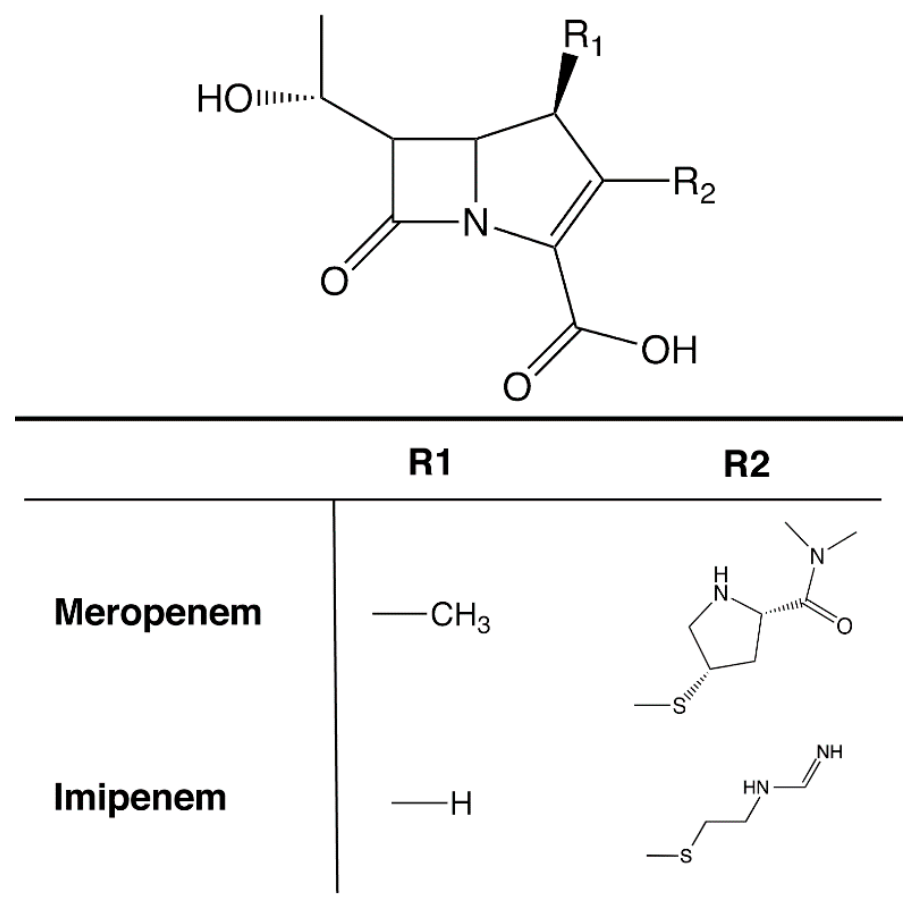

Figure 1. Structure of carbapenems. Generic chemical structure of carbapenems. The R1 and R2 groups for imipenem and meropenem, the most used in the clinics, are shown.

\section{Mechanisms of Resistance to Carbapenems in A. baumannii}

A. baumannii would not be the problematic pathogen it is without the multiple mechanisms of drug resistance the strains usually possess and its versatility to acquire new ones [9,51,136-140]. Multiple intrinsic and acquired mechanisms of resistance have been detected in A. baumannii isolates [51]. These mechanisms include enzymatic modification of the antibiotic, changes in permeability, efflux pumps, or modifications in the target sites [51,138,141-143]. Multidrug-resistant (MDR; resistance to at least three classes of antimicrobials), extensively drug-resistant (XDR; MDR plus resistance to carbapenems), and pan-drug-resistant (PDR; XDR plus resistance to polymixins) [144] A. baumannii strains are currently being isolated in clinics making treatment increasingly harder $[9,139,145-147]$. In particular, a "quantum leap" in the difficulty to treat $A$. baumannii infections occurred with the appearance of CRAB strains. Identified mechanisms of resistance to carbapenems include efflux pumps [51,148-152], reduction or inactivation of expression of porins [51,153-155], modification in expression or synthesis of new penicillin binding proteins $[156,157]$, and presence of carbapenemases. Since the latter is the most frequently observed and worrisome mechanism present in CRAB strains, in this article, we review the carbapenemases detected in this bacterium.

\section{Carbapenemases in A. baumannii: OXA $\beta$-Lactamases}

One of the most common, if not the most common, mechanisms of resistance to $\beta$-lactam antibiotics is their enzymatic hydrolysis mediated by $\beta$-lactamases [158-160]. There is more than one classification scheme for $\beta$-lactamases, which number in the hundreds, but one of the most frequently used is that proposed by Ambler (amino acid sequence-based) that divides these enzymes into four molecular classes: A, B, C, and D [160-162]. Enzymes belonging to classes A, C, and D catalyze the hydrolysis of the $\beta$-lactam substrate forming an intermediate covalent acyl-enzyme complex with a serine residue within the active site. In the case of class B $\beta$-lactamases, the hydrolysis reaction is mediated by one or more zinc ions $[160,161]$. OXA $\beta$-lactamases are class $D$ enzymes that were originally differentiated by TEM enzymes by their ability to hydrolyze oxacillin [163]. The first OXA enzymes showed relatively narrow spectrum and were plasmid-mediated [164-167]. Later, numerous cases of proteins, encoded 
by chromosome- or plasmid-located genes, with characteristics of extended spectrum $\beta$-lactamase (ESBL) or carbapenemase OXA enzymes were described [160,163,168,169].

\subsection{OXA-23-Like Group}

The first OXA enzyme with carbapenemase activity to be identified in A. baumannii was the OXA-23 (first named ARI-1), found in an isolate from Scotland [170]. This enzyme gave the name to the first group of OXA enzymes with the capability to confer resistance to carbapenems (Table 1). Besides OXA-23, some enzymes within this group, such as OXA-27 or OXA-146, were subjected to more detailed analysis [171-173].

Table 1. OXA enzymes identified in A. baumannii *

\begin{tabular}{|c|c|c|c|c|c|}
\hline Enzyme Group & $\begin{array}{l}\text { Genetic } \\
\text { Location }\end{array}$ & $\begin{array}{l}\text { Predominant } \\
\text { Isolation } \\
\text { Countries * }\end{array}$ & Isolation Source & $\begin{array}{l}\text { Other } \\
\text { Reported } \\
\text { Species }\end{array}$ & Total Reported \\
\hline OXA-23-like & $\begin{array}{l}\text { Plasmid, } \\
\text { chromosome }\end{array}$ & $\begin{array}{l}\text { USA (564), India } \\
(125), \text { South Korea } \\
(122)\end{array}$ & $\begin{array}{l}\text { Clinical }(2,830) \\
\text { Environmental/other } \\
(1128)\end{array}$ & $\begin{array}{l}\text { Providencia } \\
\text { alcalifaciens, } \\
\text { Proteus mirabilis, } \\
\text { Klebsiella } \\
\text { pneumoniae, } \\
\text { Citrobacter } \\
\text { freundii, E. } \\
\text { coli/Shigella, } \\
\text { Serratia } \\
\text { marcescens, } \\
\text { Acinetobacter } \\
\text { non-baumannii, } \\
\text { Pseudomonas } \\
\text { aeruginosa }\end{array}$ & 4048 \\
\hline OXA-24/40-like & & $\begin{array}{l}\text { USA (100), Spain } \\
\text { (5) }\end{array}$ & $\begin{array}{l}\text { Clinical (124) } \\
\text { Environmental/other (21) }\end{array}$ & $\begin{array}{l}\text { Acinetobacter } \\
\text { non-baumannii, } \\
\text { Klebsiella } \\
\text { pneumoniae, } \\
\text { Providencia } \\
\text { rettgeri, } \\
\text { Staphylococcus } \\
\text { aureus }\end{array}$ & 162 \\
\hline OXA-51-like & & $\begin{array}{l}\text { Germany (8), Brazil } \\
(8) \text {, Japan (6) }\end{array}$ & $\begin{array}{l}\text { Clinical (39) } \\
\text { Environmental/other (20) }\end{array}$ & $\begin{array}{l}\text { Acinetobacter } \\
\text { non-baumannii, } \\
\text { Klebsiella } \\
\text { pneumoniae }\end{array}$ & 88 \\
\hline OXA-58-like & $\begin{array}{l}\text { Plasmid, } \\
\text { Chromosome }\end{array}$ & $\begin{array}{l}\text { USA (84), Spain } \\
\text { (12), Thailand (8) }\end{array}$ & $\begin{array}{l}\text { Clinical (90) } \\
\text { Environmental/other } \\
(177)\end{array}$ & $\begin{array}{l}\text { Providencia } \\
\text { alcalifaciens, } \\
\text { Klebsiella } \\
\text { pneumoniae, E. } \\
\text { coli/Shigella, } \\
\text { Proteus mirabilis, } \\
\text { Enterobacter sp., } \\
\text { Acinetobacter } \\
\text { non-baumannii. }\end{array}$ & 284 \\
\hline OXA-143-like & & Brazil (3) & Clinical (3) & $\begin{array}{l}\text { Acinetobacter } \\
\text { non-baumannii }\end{array}$ & 15 \\
\hline
\end{tabular}

* The number of isolates was calculated using the US National Library of Medicine Pathogen Detection tool (https://www.ncbi.nlm.nih.gov/pathogens) and complemented using Blast [174]. Enzymes in each group have 90\% identity and $96 \%$ coverage.

The $b l a_{\mathrm{OXA}-23}$ gene is thought to have originated in $A$. radioresistens where close relatives are found located within the chromosome contiguous to a gene potentially coding for an ATPase $[175,176]$. After the first identification, the bla $a_{\mathrm{OXA}-23}$ gene was detected in A. baumannii isolates from several countries, usually as part of Tn2006, Tn2007, Tn2009, Tn2008, and Tn2008B (Figure 2). In all these elements, the $b l a_{\mathrm{OXA}-23}$ is preceded by an IS element, ISAba1 or ISAba4, and contiguous to a truncated version of the ATPase $[175,177]$. Tn2006 has the typical structure of a composite transposon where the 
$b l a_{\mathrm{OXA}-23}$ is part of a DNA stretch also containing the truncated ATPase gene and two genes, one of them coding for a helicase $[177,178]$. Tn2008 and Tn2008B consist of a copy of ISAba1 associated to the fragment including $b l a_{\mathrm{OXA}-23}$ and the incomplete ATPase gene (Figure 2). The difference between these two elements is the number of nucleotides between the ISAba1 and the OXA-23 initiation of translation codon, 27 and 34, respectively [177]. The ISAba1-bla OXA-23-helicase region, i.e., the complete Tn2008 sequence, is contained within Tn2006. Furthermore, Tn2009 is a larger derivative of Tn2006 that acquired a DNA fragment between both ISAba1 copies [177]. Tn2006, Tn2008, and Tn2009 have been found within plasmids in addition to the chromosome $[175,177,179,180]$. Tn2007, detected in plasmids, consists of a DNA fragment including $b a_{\mathrm{OXA}-23}$ and a truncated version of the helicase gene preceded by a copy of ISAb4 (Figure 2) [177]. Table 1 summarizes the number of OXA-23-like enzymes identified to date. 


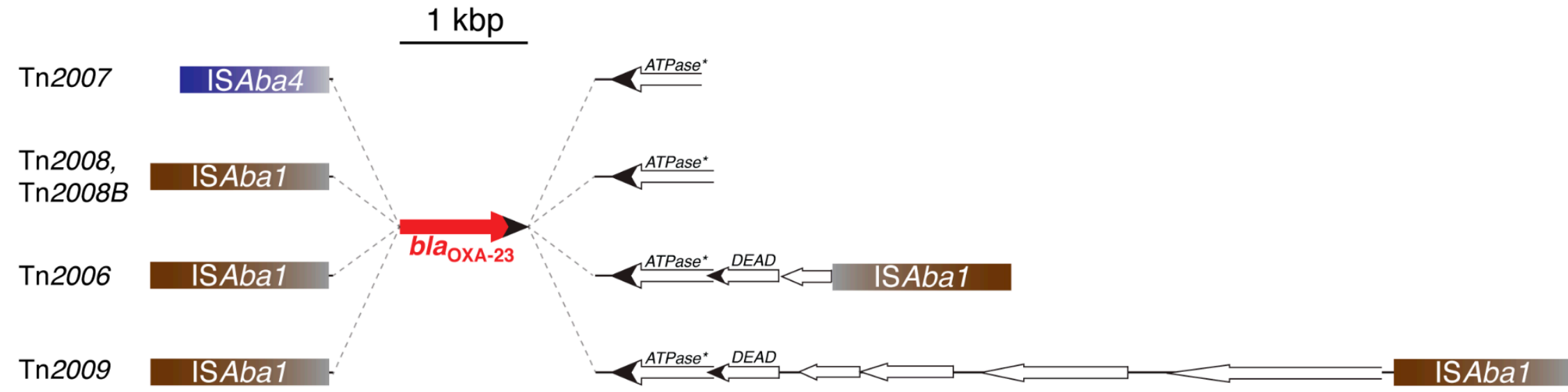

Figure 2. Genetic structures of bla OXA-23-containing elements. The structure of Tn2007, which has not been proven to transpose, is shown on top. Tn2008 and Tn2008B differ in the number of nucleotides (27 and 34, respectively) that separate bla OXA-23 from ISAba1. Tn2006, the only structure experimentally shown to transpose [178], includes copies of ISAba1 in opposite orientations, while Tn2009 carries these insertion sequences in the same orientation. These two transposons are the only ones with the typical composite transposon structure. An extensive and detailed description of these elements was recently published [177]. ATPase*, gene coding for a putative ATPase truncated at the N-terminus. DADE, gene coding for a putative DEAD box family helicase [181]. Figure interpreted from Nigro and Hall (2016) [177]. 


\subsection{OXA-24/40-Like Group}

The number of beta-lactamases belonging to the OXA-24/40 group is less than that of the OXA-23 group and others to be discussed below. The first representative of this group to be isolated from A. baumannii was OXA-24, now known as OXA-40 after sequencing revision showed that they were identical enzymes $[150,182]$. The number of genes in this group, species that were found, and genetic location are shown in Table 1. Some plasmid-mediated genes belonging to the bla $a_{\mathrm{OXA} 24 / 40 \text {-like were }}$ found flanked by Xer site-specific recombination target sites, which led researchers to propose that this recombination mechanism plays a role in mobilization of these genes at the molecular level [183-185]. Xer site-specific recombination has been associated with plasmid evolution [186-188]. Structural studies showed that OXA-24/40 specifically utilizes carbapenems as substrate through a hydrophobic barrier for which the side chains of amino acids Y112 and M223 are essential [189]. This structure forms a tunnel-like entrance (hydrophobic bridge) to the active site. OXA-40 was also crystallized in complex to doripenem and inhibitors $[190,191]$. These studies were extended and details about the mechanism by which inhibitors inactivate OXA-24/40, such as decarboxylation of a K residue within, were clarified $[189,191,192]$. A clinical variant of OXA-24/40 identified in a clinical A. baumannii isolate has the mutation P227S, which results in an expanded substrate range that includes cephalosporins and aztreonam [193].

\subsection{OXA-51-Like Group}

OXA- 51 was initially found as a chromosomally-mediated $\beta$-lactamase in a clinical A. baumannii isolate from Argentina [194]. Further studies showed the existence of numerous members of what is called the OXA-51-like group of enzymes [163]. The number of genes in this group, species that were found, and genetic location are shown in Table 1. Studies on the OXA-51 enzyme also showed that $b l a_{\mathrm{OXA}}-51$-like genes are specific to the $A$. baumannii chromosome. As a consequence, $b l a_{\mathrm{OXA}-51-\text { like }}$ genes are used as a landmark in the identification of Acinetobacter isolates as A. baumannii $[195,196]$. A review describing available methodologies and their effectivity to identify A. baumannii has been recently published [197]. In contrast, identification of $A$. baumannii using bla ${ }_{\text {OXA-51-like }}$ as a marker can present difficulties. Although these genes are mostly located within the chromosome, a few cases of plasmid location have been detected [198]. Plasmid-mediated bla $a_{\mathrm{OXA} \text {-51-like }}$ was the cause of misidentification of three non-baumannii Acinetobacter isolates that potentially acquired the gene from a plasmid originated in A. baumannii [199]. A. baumannii isolates from an outbreak in a hospital in Iran were hard to identify because the bla OXA-51-like was interrupted by an insertion of ISAba19 [200].

Early biophysical and biochemical studies on OXA-51 showed that the protein did not significantly denature when exposed to broad $\mathrm{pH}(4-10)$ and temperature $\left(30-60{ }^{\circ} \mathrm{C}\right)$ ranges, and up to $75 \%$ of the enzymatic activity was retained in these conditions [201]. Enzymatic studies showed that OXA-51-like is a weak carbapenemase and the question of whether this enzyme or others within this group are responsible for carbapenem-resistance was the focus of numerous studies [152,163,198,202-204]. Various $b l a_{\text {OXA51-like }}$ genes were found associated to ISAbA1, which, when in the proper orientation, enhances expression and alone or in association with expression of other mechanisms can lead to phenotypic resistance to carbapenems [204-206]. However, levels of expression may not be the only way OXA-51-like enzyme confers diminished susceptibility to carbapenems. Variants with one or more amino acid substitutions with respect to OXA-51 exhibit enhanced hydrolytic activity [205,207-212]. The molecular bases of several of these changes in activity associated to amino acids substitution were investigated by comparison of the three-dimensional structure of OXA-51 and the variant OXA-51 I129L in complex with doripenem $[207,213]$. This substitution increases the affinity of the protein for carbapenem molecules such as doripenem and imipenem. Variants including the substitution I129L show a significant increase in hydrolytic activity [208]. The results of the comparative analysis of these structures indicate that the presence of a Leu residue instead of Ile at position 129 causes the protein to better accommodate the substrate, increasing affinity and concomitantly enzymatic activity $[207,213]$. 
In conclusion, different OXA-51-like enzymes confer different degrees of or no clinical resistance to carbapenems, and they serve as a tool for molecular epidemiology of A. baumannii.

\subsection{OXA-58-Like Group}

This is a group of enzymes with a reduced number of variants (Table 1 ). The first $b l a_{\text {OXA-58 }}$ gene was present in a non-self-transmissible 30-kbp plasmid residing in a multiresistant $A$. baumannii isolated in the Rangueil University hospital, Toulouse, France [214]. The gene was flanked by ISAba3-like insertion element copies in opposite orientations. The same gene was detected in seven carbapenem-resistant isolates, six from patients, and one from the environment, in the burns unit of the same hospital [215], and rapidly spread to other countries [216]. A recent study showed that an A. seifertii plasmid is $99 \%$ homologous to one from $A$. baumannii, but the ISAba3-like insertion element located upstream of $b l a_{\mathrm{OXA}}-58$ is interrupted by a copy of ISAba825 [217]. These studies argue in favor of horizontal transmission as the main mechanism of dissemination of bla $a_{\mathrm{OXA}-58 \text {-like }}$ genes. Due to the difference in GC percent found between the gene and the A. baumannii chromosome, it is currently thought that $b l a_{\text {OXA-58-like }}$ genes originated in a different bacterium [163].

The $b a_{\text {OXA-58 }}$ gene was carried by plasmids harbored by six clonally related A. baumannii strains isolated in 2005 from a hospital in Rome, Italy. The strains showed different levels of resistance to carbapenems, and the plasmids were nearly identical but differed at the regions carrying the $b l a_{\mathrm{OXA}}-58$ gene. A structure consisting of IS26-ISAba2- bla $a_{\mathrm{OXA}-58}$-ISAba3 was identified that can induce amplification of the gene, producing an increase in MIC by gene dosage [218]. Gene amplification can occur through a wide variety of mechanisms [218], and its role in increasing levels of resistance has been shown multiple times [219-223].

\subsection{OXA-143-Like Group}

OXA-143 was first identified in a $\sim 30-\mathrm{kbp}$ plasmid present in an A. baumannii blood culture isolate from a patient in an intensive care unit in Brazil in 2004 (Table 1) [224]. OXA-143 hydrolyzed penicillin and carbapenems but did not significantly hydrolyze expanded-spectrum cephalosporins. The $b l a_{\mathrm{OXA}-143}$ gene was neither associated with insertion sequences nor located within an integron, but later, at least a $b l a_{\mathrm{OXA}-143-\text { like }}$ gene, $b l a_{\mathrm{OXA}-253}$, was located in a plasmid, downstream of ISAba47 [225]. On the other hand, bla $a_{\mathrm{OXA}-143}$ and a downstream gene were flanked by copies of a gene coding for a replication protein, suggesting that its incorporation in the plasmid could have occurred by homologous recombination [224]. The OXA-143 amino acid sequence shows $88 \%, 63 \%$, and $52 \%$ identity with OXA-40, OXA-23, and OXA-58, respectively. Later, other OXA-143-like enzymes were isolated in Brazil, Korea, Peru, and Honduras [225-230]. On the basis of the GC percent, these genes, which are located in plasmids, seem to have originated in a different Acinetobacter species [163].

\subsection{OXA-235-Like Group}

The OXA-235 and two variants, OXA-236 and OXA-237, which have one amino acid substitution (OXA-236 G173V and OXA-237 D208G), were identified in nine A. baumannii strains from the US and Mexico [231]. Location of the genes coding for these enzymes was chromosome or plasmid, with some strains showing positive signal within a plasmid and colocalization with $b l a_{\mathrm{OXA}-51}$. In all nine isolates having the $b l a_{\mathrm{OXA}-235}$, the gene was flanked by two copies of ISAba1. In a surveillance study performed between 2010 and 2016 in Canadian acute care hospitals, 94 carbapenem-resistant Acinetobacter sp. strains, of which 90 were A. baumannii, were selected for further analysis [232]. OXA-235-like proteins

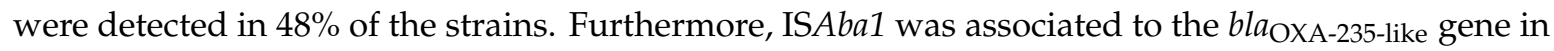
all $A$. baumannii strains.

An outbreak that occurred across five healthcare facilities in Oregon, US, and lasted from June 2012 to October 2014, affected 16 patients and was caused by extensively drug-resistant $A$. baumannii [233]. The resistance to carbapenem was caused by the presence of the $b l a_{\mathrm{OXA}-235-l i k e}$ gene $b l a_{\mathrm{OXA}-237}$, which was flanked by ISAba1 elements in opposite orientations in a 15.198-kbp plasmid present in all 16 
isolates $[233,234]$. It was of special concern that $b l a_{\mathrm{OXA}-237}$ is plasmid-mediated, a characteristic that enhances the potential for dissemination, and was found in a strain belonging to clonal group IC2, the most prominent worldwide [234].

\section{Carbapenemases in A. baumannii: Metallo- $\beta$-Lactamases}

The mechanism used by $\beta$-lactamases to catalyze hydrolysis of the antibiotic molecule can involve a two-step cycle consisting of acylation by formation of an acylenzyme intermediate by establishing a covalent bond between the $\beta$-lactam and a serine residue within the enzyme's active site followed by a deacylation step or a cation-facilitated hydrolytic reaction in which one or two essential zinc ions locate at the active site of the enzyme [235]. These enzymes, known as metallo- $\beta$-lactamases or Class B $\beta$-lactamases, are subdivided into three subclasses, B1-B3 [235].

Enzymes belonging to subclasses B1 and B3 utilize two $\mathrm{Zn}^{2+}$ ions, while those within subclass B2 need just one zinc atom to catalyze inactivation. A distinctive characteristic of metallo- $\beta$-lactamases is that they are active against carbapenems [158,235-237]. There are still no inhibitors available for clinical use for metallo- $\beta$-lactamases. However, recently described compounds such as QPX7728 and VNRX-5133 (Taniborbactam) show inhibition activity against metallo- $\beta$-lactamases. Both compounds are active at nanomolar concentrations and could be developed as part of $\beta$-lactam/ $\beta$-lactamase inhibitor formulations against metallo- $\beta$-lactamases [238-240].

\subsection{NDM Group}

NDM-1 is a metallo- $\beta$-lactamase (New Delhi metallo- $\beta$-lactamase) first isolated in India in 2008 from a patient with a urinary tract infection caused by a carbapenem-resistant Klebsiella pneumoniae [241]. The $b l a_{\mathrm{NDM}-1}$ gene, located adjacent to a truncated IS26 element, was part of a 180-kbp plasmid that includes genetic determinants that confer resistance to all antibiotics except fluoroquinolones and colistin. It was also troublesome that an E. coli strain isolated form the same patient harbored a plasmid containing $b l a_{\mathrm{NDM}-1}$, suggesting that transfer by conjugation occurs at high frequency. This possibility was supported in mating assays and the authors predicted a worrisome scenario where the gene would spread to other bacteria [241]. Unfortunately, the predictions were correct, and bacteria harboring a plasmid containing the $b l a_{\mathrm{NDM}-1}$ gene were soon isolated in infections across the world, [8,242-246].

A search at the National Center for Biotechnology Information Pathogen Detection Browser (https://www.ncbi.nlm.nih.gov/pathogens) performed at the time this article was being written produced 2407 isolates carrying NDM-1. The number of NDM-1-possesing A. baumannii strains was 240, only surpassed by K. pneumoniae (1527) and Escherichia coli/Shigella (265 combined).

Except for monobactams, NDM-1 confers resistance to all other $\beta$-lactams [247]. Twenty-seven variants were described in addition to NDM-1 that present amino acid substitutions, and in one case there is a 5-amino acid repeat. A detailed description of the NDM-1 variants has been recently published [243]. According to this publication and newer data, NDM-1, NDM-2, NDM-3, NDM-5, and NDM-7 have been detected in A. baumannii [243,248,249]. Unfortunately, $b l a_{\mathrm{NDM}-1}$ is usually associated to other genetic determinants that specify resistance to numerous antibiotics leaving only last-line antimicrobials, usually used in combination therapies, as options for treatment [250-252]. While the bla $a_{\mathrm{NDM}-1}$ gene was found in more than one genetic context, in all cases described to date it is located downstream of ISAb125 sequences that provide the -35 region of the promoter [243]. In some instances, there is complete copy of the insertion sequence and in others only a fragment (identified as ISAba125*) [253]. This structure is associated to other genes, in many cases flanked by insertion sequences to form a composite transposon [243]. In most, but not all, cases, downstream of bla $a_{\mathrm{NDM}-1}$, there is a ble $e_{\mathrm{MBL}}$ gene (resistance to bleomycin) followed by $\operatorname{trpF}$ (phosphoribosylanthranilate isomerase), and $d s b C$ (tat twin-arginine translocation pathway signal sequence domain protein). Other genes that usually follow these genes are cutA1 (periplasmic divalent cation tolerance protein) and groES-groEL (chaperonin) [243,254,255]. In many instances, this structure is followed by a copy of ISCR27 like in the A. baumannii transposon Tn125 and other 
elements (Figure 3) [256-259]. These structures are found flanked by different elements that imply the existence of a wide variety of mechanisms of dissemination [243,253,255,260-263]. In those cases where the structure is part of a composite transposon, this cluster of genes is flanked by ISAba125 (forming Tn125) [257], IS903, IS26, or IS3000, in direct or opposite orientations [243,252,253,256,264]. The structure ISAba125*-bla $a_{\mathrm{NDM}-1}-b l e_{\mathrm{MBL}}-\operatorname{trpF}-d s b C$-cutA1-groES-groEL has been also found flanked by short repeats with features characteristic of miniature inverted repeat elements [254].

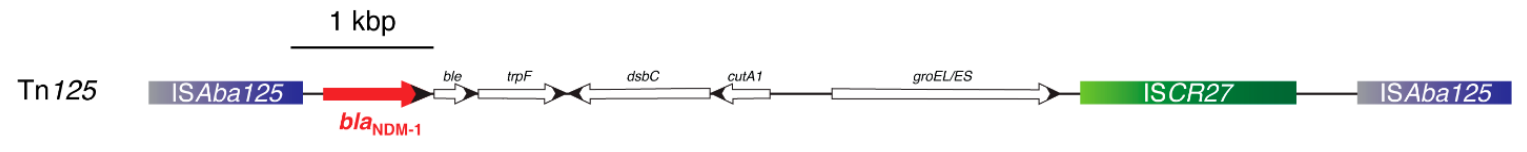

Figure 3. Genetic map of A. baumannii transposon Tn125. Figure interpreted from Poirel et al. [257].

As it is the case with other resistance proteins like the pJHCMW1-coded AAC $\left(6^{\prime}\right)-\mathrm{Ib}$, which has a fusion at the N-terminus where the first six amino acids are identical to those of the TEM $\beta$-lactamase [141,142,166], analysis of the nucleotide sequence of $b l a_{\mathrm{NDM}-1}$ and the upstream region showed that the first 6 amino acids of the protein are identical to those of the aminoglycoside phosphotransferase $\mathrm{APH}\left(3^{\prime}\right)$-Via [256], a protein associated to A. baumannii strains [265]. Furthermore, the GC content of the gene changes abruptly at the point of divergence. These facts, together with the known association of ISAba125 to A. baumannii, led to propose that $b l a_{\mathrm{NDM}-1}$ originated through a fusion that took place in this bacterium [256]. With a few exceptions in which $b l a_{\mathrm{NDM}-1}$ was found located within the chromosome, the gene is harbored in plasmids. Upwards of 350 different plasmids and 20 replicons harboring $b l a_{\mathrm{NDM}}$ genes were described [243]. The rich number of plasmid varieties and transposable elements that carry $b l a_{\mathrm{NDM}}$ genes explain their fast dissemination at the molecular and cellular levels [243]. The structure and biochemistry of NDM-1 has been thoroughly studied [252,266-271].

An interesting feature of NDM-1 is related to its dependence on zinc ions, a property shared with other metallo- $\beta$-lactamases. It is well known that one of the mammals' innate immune responses to bacterial infections is the chelation of metal ions by high-affinity binding proteins $[272,273]$. Calprotectin, an important component of the cytosolic protein pool, was first identified by its ability to interfere with the growth of fungal and bacterial pathogens [274]. This property seems to be related to its ability to bind $\mathrm{Zn}^{2+}$ with high affinity. Calprotectin is released at the infection foci in the body, and one of its effects is to reduce the action of metallo- $\beta$-lactamases and induce degradation because the apo-enzyme is degraded in the periplasm [275]. Many metallo- $\beta$-lactamases elude this defense mechanism by being very efficient at binding the scarce zinc ions present in the periplasmic space [275]. NDM-1 differs from most metallo- $\beta$-lactamases in that limitation of zinc ions does not result in degradation because it is anchored to the outer membrane, a property that makes it refractory to destabilization [276]. Furthermore, this feature results in secretion of the protein with the release of outer membrane vesicles that shield infecting bacterial cells from high levels of $\beta$-lactams in their environment $[276,277]$.

\subsection{VIM Group}

This type of metallo- $\beta$-lactamases were first identified in Pseudomonas aeruginosa isolates in Italy and France $[278,279]$. The variants were denominated VIM-1 and VIM-2, respectively, and were part of gene cassettes as part of class 1 integrons. However, while VIM-1-carrying integron was located within the chromosome and included a second $a a c\left(6^{\prime}\right)$-Ib-containing gene cassette in its variable region, the VIM-2-carrying integron was part of a $\sim 45-\mathrm{kbp}$ non conjugative plasmid and possessed a unique gene cassette. The geographical location of the first detection of these enzymes and their genetic environment are represented in the VIM name of the group (Verona integron-related metallo- $\beta$-lactamase). After the first identification, the number of VIM variants increased rapidly, mainly found in Enterobacteriaceae [160,280,281]. Forty-six VIM variants were identified in a search at the National Center for Biotechnology Information Pathogen Detection Browser 
(https://www.ncbi.nlm.nih.gov/pathogens) but 70 are presently uploaded in GenBank. Early studies to identify metallo- $\beta$-lactamases in a collection of isolates from Korean hospitals showed that in one study an A. baumannii isolate and in the other 27 out of 38 tested Acinetobacter spp. samples carried VIM-2 [282,283]. Five unrelated A. baumannii isolates obtained in two Greek hospitals in the years 2004 and 2005 included a class 1 integron that carried $b l a_{\mathrm{VIM}-1}$ in the variable portion [284]. The nontransferable characteristic of $b l a_{\mathrm{VIM}-1}$ in these isolates suggests chromosomal or a nonconjugative plasmid. The gene was also detected in eight out of 13 strains tested in a study in Saudi Arabia and Iran where $b l a_{\mathrm{VIM}-2}$ was also present [285-287]. Both $b l a_{\mathrm{VIM}-1}$ and $b l a_{\mathrm{VIM}-2}$ were also detected in a study of 100 A. baumannii isolates from three teaching hospitals in Iran [288]. Other VIM-type enzymes identified in A. baumannii were VIM-3 and VIM-11 in strains from a university hospital in Taiwan [289]. Several studies identified unspecified VIM-type enzymes in A. baumannii clinical isolates [290-296]. Blast analysis, carried out at the time of writing of this article, demonstrated that the genes coding for VIM-6, VIM-11, and VIM-25 were also detected in A. baumannii.

\subsection{IMP Group}

The first metallo- $\beta$-lactamase in the IMP (active on imipenem) group was identified in an imipenem-resistant $P$. aeruginosa clinical strain collected in 1988 in Japan [297]. The $b a_{\text {IMP }}$ gene resided in a conjugative 47.7-kbp plasmid, pMS350, belonging to the P-9 incompatibility group that also conferred resistance to gentamicin and sulfonamide [297]. The bla $\mathrm{I}_{\mathrm{MP}}$ gene was then found in the chromosome and as part of an integron in a transferable plasmid of urinary tract infection Serratia marcescens isolates from Japan [298-300]. Rapid dissemination was soon described, an expected outcome due to the location in transferable plasmids. P. aeruginosa and K. pneumoniae clinical strains carrying $b l a_{\mathrm{IMP}}$ were identified, and a six-years study at the Nagasaki University Hospital, Japan, identified $b a_{\mathrm{IMP}}$ in 80 clinical strains belonging to the species P. aeruginosa, P. putida, P. stutzeri, and Citrobacter freundii [301-303]. The first report of an IMP-type enzyme in Europe occurred in a multidrug-resistant $A$. baumannii strain isolated from the respiratory tract of an intensive care unit patient in Italy. Further analysis showed that the gene coded for IMP-2 and was carried in a gene cassette as part of a class I integron located in the chromosome (Figure 4) [304,305]. The bla IMP-2 gene cassette was located downstream of intI1, and the variable region also included $a a c\left(6^{\prime}\right)-I b$ and ant $\left(3^{\prime \prime}\right)-I a[304]$. A Blast comparison between the $a a c\left(6^{\prime}\right)-I b-a n t\left(3^{\prime \prime}\right)$-Ia region from this transposon and that one from the Tn1331 [306-308] showed 99\% homology with divergence at the point of action of IntI1 at the N-terminus coding sequences of $a a c\left(6^{\prime}\right)-\mathrm{Ib}$, a well-known characteristic of this gene that exhibits heterogeneous N-termini [141,309-311] (Figure 4). The second identification of an IMP-type enzyme in Europe was also on a nosocomial A. baumannii isolate in Portugal. Analysis of this gene concluded that it was a new member, named $b l a_{\mathrm{IMP}-5}$ because $b l a_{\mathrm{IMP}-3}$ and $b l a_{\mathrm{IMP}-4}$ had been identified earlier in Asia [312-315]. IMP-4 was later found within a class 1 integron in A. baumannii isolates [316] and in similar integrons in A. pitti, K. pneumoniae, E. coli, and Enterobacter cloacae strains. In the cases of the E. coli and two E. cloacae strains, it was confirmed that the gene resided in a plasmid $[317,318]$. The genetic context of $b l a_{\mathrm{IMP}-4}$ present in A. junii was not determined [319]. To date, A. baumannii strains carrying $b l a_{\mathrm{IMP}-1}, b l a_{\mathrm{IMP}-2}, b l a_{\mathrm{IMP}-4}, b l a_{\mathrm{IMP}-5}, b l a_{\mathrm{IMP}-6}, b l a_{\mathrm{IMP}-8}, b l a_{\mathrm{IMP}-11}, b l a_{\mathrm{IMP}-14 a}, b l a_{\mathrm{IMP}-19}$, and $b l a_{\mathrm{IMP}-55}$, have been reported. The $b l a_{\mathrm{IMP}-55}$ was identified in a study of 65 multidrug-resistant A. baumannii strains isolated in two intensive care units in Iran which showed that 6 of them contained integrons including $b l a_{\mathrm{IMP}-55}$ genes [320].

A search at the National Center for Biotechnology Information Pathogen Detection Browser (https://www.ncbi.nlm.nih.gov/pathogens) found 85 variants of IMP metallo- $\beta$-lactamases and 865 IMP-carrying isolates, the vast majority of which were P. aeruginosa (240 strains), Enterobacter (215 strains), and K. pneumoniae (184 strains). Forty-one IMP-carrying A. baumannii isolates were found in this search, the most prevalent variants in this bacterium were IMP-1 (21 strains) and IMP-4 (3 strains). 


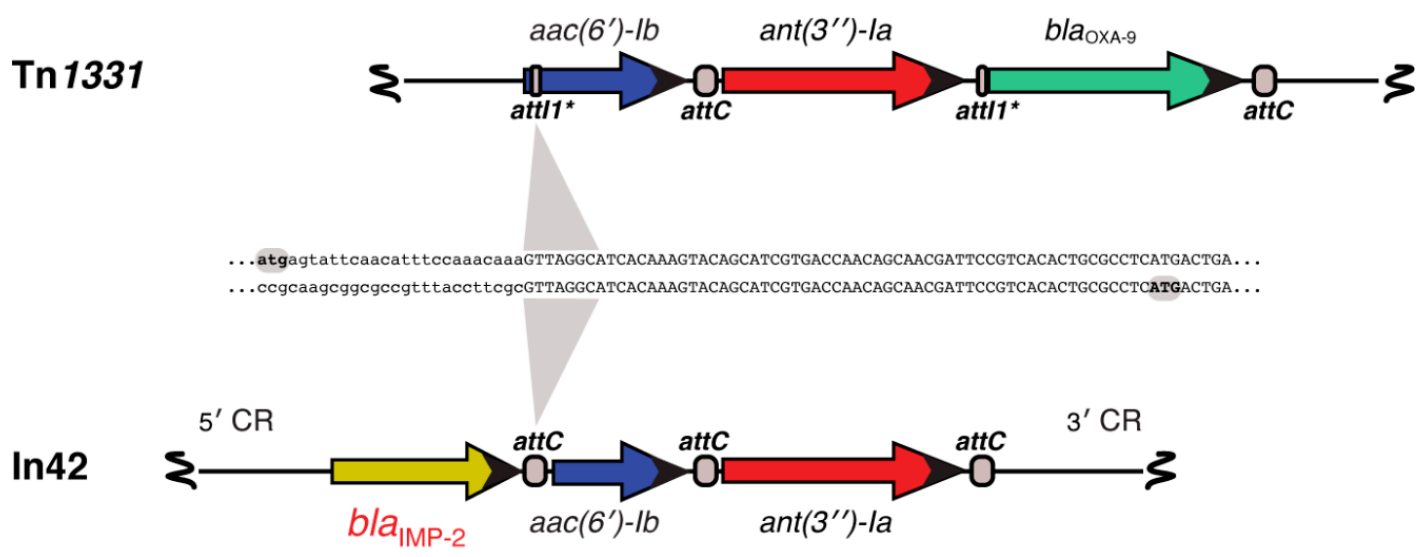

Figure 4. Comparison of the In42 variable region and a Tn1331 resistance genes fragment. The genetic maps of the variable region of In42 and a resistance genes fragment of Tn1331 are aligned. All attC loci are shown equally in the figure, but they are not identical at the nucleotide sequence level. The attI1* structure and functionality have been described [306]. The aac ( $\left.6^{\prime}\right)$-Ib genes code for proteins that show differences at the N-termini, a known characteristic of this gene $[141,309,310]$.

\section{Carbapenemases in A. baumannii: KPC $\beta$-Lactamases}

Enzymes within the KPC (K. pneumoniae carbapenemase) group are class A serine carbapenem-hydrolyzing $\beta$-lactamases that were initially reported in 2001, when KPC-1 was identified in a K. pneumoniae strain collected in 1996 from a hospital in North Carolina [321]. The gene quickly disseminated among Klebsiella strains and other bacteria and a high percentage of multidrug-resistant isolates were found to carry a $b l a_{\mathrm{KPC}}$ gene [322-330]. Unfortunately, bacteria carrying KPC enzymes are usually multidrug resistant, which seriously limits the antibiotic options for treatment; as a consequence, mortality among patients infected with KPC-harboring bacteria is high [328]. Interestingly, in some locations, there has been a decline in the isolates harboring these genes [325,331]. The quick and efficient dissemination of bla $a_{\mathrm{KPC}}$ genes is due to their usual location within transposable elements, mainly Tn4401 or close relatives [332] in conjugative plasmids [333-336]. Tn4401 is also commonly inserted within other transposon or insertion sequences generating multidrug resistance transposable elements $[337,338]$. It is worth noting that although unusual, bla $a_{\mathrm{KPC}}$ genes are found associated to non-Tn4401 genetic environments [339-341]. A search at the National Center for Biotechnology Information Pathogen Detection Browser (https://www.ncbi.nlm.nih.gov/pathogens) found 47 variants of KPC and 8716 records. There are numerous reports of $A$. baumannii carrying undetermined $b l a_{\mathrm{KPC}}$ genes [294,342,343]. Confirmed variants of bla $a_{\mathrm{KPC}}$ found in A. baumannii include bla $a_{\mathrm{KPC}-2}$ and bla $a_{\mathrm{KPC}-3}$, first identified in a study to characterize the resistance to carbapenem in A. baumannii (CRAB) isolates from patients with burn injury in Brazil [344]. Moreover, a study of Acinetobacter isolates from 17 hospitals in Puerto Rico identified $b l a_{\mathrm{KPC}-4}$ and $b l a_{\mathrm{KPC}-10}$ [345].

Enzymes belonging to the KPC group are the only ones that recognize as substrates all FDA-approved $\beta$-lactams. KPCs are inhibited by avibactam, relebactam, and vaborbactam [160,326,346-351]. Inhibition of KPC enzymes by clavulanate, tazobactam, and sulbactam is minimal [352].

\section{Final Remarks}

A. baumannii emerged as a problematic nosocomial pathogen in the mid-1980s, when acquisition of resistance traits became significant, making treatment more challenging [11,353]. The genetic plasticity of Acinetobacter spp. permitted this bacterium to evolve rapidly, turning it into one the most serious threats to hospitalized patients [52,53,354-356]. Currently, multi- and pan-drug-resistant A. baumannii are ubiquitous, and options for treatment are shrinking. The rise of carbapenem-resistant A. baumannii strains (CRABs) further compounds the problem, which requires urgent attention to avoid 
expanding the number of deaths due to nosocomial infection. Among the many mechanisms causing resistance, the acquisition of carbapenemase-coding genes are the most relevant. The majority of carbapenem-resistant $A$. baumannii isolates owes this property to the presence of OXA- 23 . The prevalence of $b l a_{\mathrm{OXA}-23}$ is, at least in part, attributed to the spread of successful global clones such us GC1 and GC2. However, the number of isolates containing NDM-1 is rapidly growing. Research efforts geared to developing new antimicrobials must be complemented with strategies to overcome the presence of these enzymes such as the introduction of new inhibitors to be used in combination with antibacterial drugs. Despite the grim perspective of witnessing the rise of strains resilient to all available treatments, investigative attempts to introduce new inhibitors and drugs give hope that options to control these infections will continue to be available.

Author Contributions: Conceptualization, M.S.R., R.A.B., and M.E.T.; writing一original draft preparation, M.E.T.; writing-review and editing, M.S.R., R.A.B., and M.E.T. All authors have read and agreed to the published version of the manuscript.

Funding: Authors' work cited in this review article was funded by Public Health Service Grants SC3GM125556 (MSR), 2R15AI047115 (MET), R01AI100560 (RAB), R01AI063517 (to RAB), and R01AI072219 (to RAB) from the National Institutes of Health and VA 1I01BX001974 (to RAB) form the Cleveland Department of Veterans Affairs. The content is solely the responsibility of the authors and does not necessarily represent the official views of the National Institutes of Health or the Department of Veterans Affairs.

Conflicts of Interest: The authors declare no conflict of interest.

\section{References}

1. Giamarellou, H.; Antoniadou, A.; Kanellakopoulou, K. Acinetobacter baumannii: A universal threat to public health? Int. J. Antimicrob. Agents 2008, 32, 106-119. [CrossRef] [PubMed]

2. Fournier, P.E.; Richet, H. The epidemiology and control of Acinetobacter baumannii in health care facilities. Clin. Infect. Dis. 2006, 42, 692-699. [CrossRef] [PubMed]

3. Actis, L.A.; Tolmasky, M.E.; Crosa, L.M.; Crosa, J.H. Effect of iron-limiting conditions on growth of clinical isolates of Acinetobacter baumannii. J. Clin. Microbiol. 1993, 31, 2812-2815. [CrossRef]

4. Hartstein, A.I.; Rashad, A.L.; Liebler, J.M.; Actis, L.A.; Freeman, J.; Rourke, J.W., Jr.; Stibolt, T.B.; Tolmasky, M.E.; Ellis, G.R.; Crosa, J.H. Multiple intensive care unit outbreak of Acinetobacter calcoaceticus subspecies anitratus respiratory infection and colonization associated with contaminated, reusable ventilator circuits and resuscitation bags. Am. J. Med. 1988, 85, 624-631. [CrossRef]

5. Hartstein, A.I.; Morthland, V.H.; Rourke, J.W., Jr.; Freeman, J.; Garber, S.; Sykes, R.; Rashad, A.L. Plasmid DNA fingerprinting of Acinetobacter calcoaceticus subspecies anitratus from intubated and mechanically ventilated patients. Infect. Control. Hosp. Epidemiol. 1990, 11, 531-538. [CrossRef]

6. Larson, E. A decade of nosocomial Acinetobacter. Am. J. Infect. Control 1984, 12, 14-18. [CrossRef]

7. Bergogne-Berezin, E.; Towner, K.J. Acinetobacter spp. as nosocomial pathogens: Microbiological, clinical, and epidemiological features. Clin. Microbiol. Rev. 1996, 9, 148-165. [CrossRef]

8. CDC. Antibiotic resistance threats in the United States; Centers for Disease Control: Atlanta, GA, USA, 2019.

9. Isler, B.; Doi, Y.; Bonomo, R.A.; Paterson, D.L. New treatment options against carbapenem-resistant Acinetobacter baumannii infections. Antimicrob. Agents Chemother. 2019, 63, e01110-18. [CrossRef]

10. McConnell, M.J.; Actis, L.; Pachon, J. Acinetobacter baumannii: Human infections, factors contributing to pathogenesis and animal models. FEMS Microbiol. Rev. 2013, 37, 130-155. [CrossRef]

11. Peleg, A.Y.; Seifert, H.; Paterson, D.L. Acinetobacter baumannii: Emergence of a successful pathogen. Clin. Microbiol. Rev. 2008, 21, 538-582. [CrossRef]

12. Tomaras, A.P.; Dorsey, C.W.; Edelmann, R.E.; Actis, L.A. Attachment to and biofilm formation on abiotic surfaces by Acinetobacter baumannii: Involvement of a novel chaperone-usher pili assembly system. Microbiology 2003, 149, 3473-3484. [CrossRef] [PubMed]

13. Tomaras, A.P.; Flagler, M.J.; Dorsey, C.W.; Gaddy, J.A.; Actis, L.A. Characterization of a two-component regulatory system from Acinetobacter baumannii that controls biofilm formation and cellular morphology. Microbiology 2008, 154, 3398-3409. [CrossRef] [PubMed]

14. Nemec, A.; Krizova, L.; Maixnerova, M.; van der Reijden, T.J.; Deschaght, P.; Passet, V.; Vaneechoutte, M.; Brisse, S.; Dijkshoorn, L. Genotypic and phenotypic characterization of the Acinetobacter 
calcoaceticus-Acinetobacter baumannii complex with the proposal of Acinetobacter pittii sp. nov. (formerly Acinetobacter genomic species 3) and Acinetobacter nosocomialis sp. nov. (formerly Acinetobacter genomic species 13TU). Res. Microbiol. 2011, 162, 393-404. [PubMed]

15. Traglia, G.; Chiem, K.; Quinn, B.; Fernandez, J.S.; Montana, S.; Almuzara, M.; Mussi, M.A.; Tolmasky, M.E.; Iriarte, A.; Centron, D.; et al. Genome sequence analysis of an extensively drug-resistant Acinetobacter baumannii indigo-pigmented strain depicts evidence of increase genome plasticity. Sci. Rep. 2018, 8, 16961. [CrossRef]

16. Xu, A.; Zhu, H.; Gao, B.; Weng, H.; Ding, Z.; Li, M.; Weng, X.; He, G. Diagnosis of severe community-acquired pneumonia caused by Acinetobacter baumannii through next-generation sequencing: A case report. BMC Infect. Dis. 2020, 20, 45. [CrossRef]

17. Chen, C.T.; Wang, Y.C.; Kuo, S.C.; Shih, F.H.; Chen, T.L.; How, C.K.; Yang, Y.S.; Lee, Y.T. Community-acquired bloodstream infections caused by Acinetobacter baumannii: A matched case-control study. J. Microbiol. Immunol. Infect. 2018, 51, 629-635. [CrossRef]

18. Leung, W.S.; Chu, C.M.; Tsang, K.Y.; Lo, F.H.; Lo, K.F.; Ho, P.L. Fulminant community-acquired Acinetobacter baumannii pneumonia as a distinct clinical syndrome. Chest 2006, 129, 102-109. [CrossRef]

19. Chen, M.Z.; Hsueh, P.R.; Lee, L.N.; Yu, C.J.; Yang, P.C.; Luh, K.T. Severe community-acquired pneumonia due to Acinetobacter baumannii. Chest 2001, 120, 1072-1077. [CrossRef]

20. Harding, C.M.; Hennon, S.W.; Feldman, M.F. Uncovering the mechanisms of Acinetobacter baumannii virulence. Nat. Rev. Microbiol 2018, 16, 91-102. [CrossRef]

21. Wong, D.; Nielsen, T.B.; Bonomo, R.A.; Pantapalangkoor, P.; Luna, B.; Spellberg, B. Clinical and pathophysiological overview of Acinetobacter infections: A century of challenges. Clin. Microbiol. Rev. 2017, 30, 409-447. [CrossRef]

22. Abbo, A.; Carmeli, Y.; Navon-Venezia, S.; Siegman-Igra, Y.; Schwaber, M.J. Impact of multi-drug-resistant Acinetobacter baumannii on clinical outcomes. Eur. J. Clin. Microbiol. Infect. Dis. 2007, 26, 793-800. [CrossRef] [PubMed]

23. Falagas, M.E.; Rafailidis, P.I. Attributable mortality of Acinetobacter baumannii: No longer a controversial issue. Crit. Care 2007, 11, 134. [CrossRef] [PubMed]

24. Garnacho, J.; Sole-Violan, J.; Sa-Borges, M.; Diaz, E.; Rello, J. Clinical impact of pneumonia caused by Acinetobacter baumannii in intubated patients: A matched cohort study. Crit. Care Med. 2003, 31, 2478-2482. [CrossRef] [PubMed]

25. Ciginskiene, A.; Dambrauskiene, A.; Rello, J.; Adukauskiene, D. Ventilator-associated pneumonia due to drug-resistant Acinetobacter baumannii: Risk factors and mortality relation with resistance profiles, and independent predictors of in-hospital mortality. Medicina (Kaunas) 2019, 55, 49. [CrossRef]

26. Dijkshoorn, L.; Nemec, A.; Seifert, H. An increasing threat in hospitals: Multidrug-resistant Acinetobacter baumannii. Nat. Rev. Microbiol. 2007, 5, 939-951. [CrossRef]

27. Wisplinghoff, H.; Paulus, T.; Lugenheim, M.; Stefanik, D.; Higgins, P.G.; Edmond, M.B.; Wenzel, R.P.; Seifert, H. Nosocomial bloodstream infections due to Acinetobacter baumannii, Acinetobacter pittii and Acinetobacter nosocomialis in the United States. J. Infect. 2012, 64, 282-290. [CrossRef]

28. Zurawski, D.V.; Banerjee, J.; Alamneh, Y.A.; Shearer, J.P.; Demons, S.T. Skin and soft tissue models for Acinetobacter baumannii infection. Methods Mol. Biol. 2019, 1946, 271-287.

29. Matthews, L.; Goodrich, J.S.; Weber, D.J.; Bergman, N.H.; Miller, M.B. The brief case: A fatal case of necrotizing fasciitis due to multidrug-resistant Acinetobacter baumannii. J. Clin. Microbiol. 2019, 57, e01751-18.

30. Guerrero, D.M.; Perez, F.; Conger, N.G.; Solomkin, J.S.; Adams, M.D.; Rather, P.N.; Bonomo, R.A. Acinetobacter baumannii-associated skin and soft tissue infections: Recognizing a broadening spectrum of disease. Surg. Infect. (Larchmt.) 2010, 11, 49-57. [CrossRef]

31. Wu, X.; Wang, L.; Ye, Y.Z.; Yu, H. Postoperative multidrug-resistant Acinetobacter baumannii meningitis successfully treated with intravenous doxycycline and intraventricular gentamicin: A case report. World J. Clin Cases 2019, 7, 4342-4348. [CrossRef]

32. Zurawski, D.V.; Thompson, M.G.; McQueary, C.N.; Matalka, M.N.; Sahl, J.W.; Craft, D.W.; Rasko, D.A. Genome sequences of four divergent multidrug-resistant Acinetobacter baumannii strains isolated from patients with sepsis or osteomyelitis. J. Bacteriol. 2012, 194, 1619-1620. [CrossRef] [PubMed]

33. Charnot-Katsikas, A.; Dorafshar, A.H.; Aycock, J.K.; David, M.Z.; Weber, S.G.; Frank, K.M. Two cases of necrotizing fasciitis due to Acinetobacter baumannii. J. Clin. Microbiol. 2009, 47, 258-263. [CrossRef] [PubMed] 
34. Sturiale, M.; Corpina, C.; Sturiale, L. Endocarditis due to Acinetobacter baumannii. Int. J. Cardiol. 2016, 209, 161-163. [CrossRef] [PubMed]

35. Kunhi, M.; Sanagar, S.; Jagadeesh, N.; Shankar, B.; Abraham, A. Emergency cardiac double valve surgery in active infective endocarditis due to Acinetobacter baumannii with aortic root abscess in a patient with dialysis-dependent end-stage renal failure: A rare case report. J. Surg Case Rep. 2016, 2016, rjw168. [CrossRef]

36. Patel, G.; Perez, F.; Hujer, A.M.; Rudin, S.D.; Augustine, J.J.; Jacobs, G.H.; Jacobs, M.R.; Bonomo, R.A. Fulminant endocarditis and disseminated infection caused by carbapenem-resistant Acinetobacter baumannii in a renal-pancreas transplant recipient. Transpl. Infect. Dis. 2015, 17, 289-296. [CrossRef]

37. Borer, A.; Gilad, J.; Smolyakov, R.; Eskira, S.; Peled, N.; Porat, N.; Hyam, E.; Trefler, R.; Riesenberg, K.; Schlaeffer, F. Cell phones and Acinetobacter transmission. Emerg. Infect. Dis. 2005, 11, 1160-1161. [CrossRef]

38. Cohen, R.; Shimoni, Z.; Ghara, R.; Ram, R.; Ben-Ami, R. Effect of a ventilator-focused intervention on the rate of Acinetobacter baumannii infection among ventilated patients. Am. J. Infect. Control 2014, 42, 996-1001. [CrossRef]

39. Villegas, M.V.; Hartstein, A.I. Acinetobacter outbreaks, 1977-2000. Infect. Control. Hosp. Epidemiol. 2003, 24, 284-295. [CrossRef]

40. Weernink, A.; Severin, W.P.; Tjernberg, I.; Dijkshoorn, L. Pillows, an unexpected source of Acinetobacter. J. Hosp. Infect. 1995, 29, 189-199. [CrossRef]

41. Farrow, J.M., 3rd; Wells, G.; Pesci, E.C. Desiccation tolerance in Acinetobacter baumannii is mediated by the two-component response regulator BfmR. PLoS ONE 2018, 13, e205638. [CrossRef]

42. Aranda, J.; Bardina, C.; Beceiro, A.; Rumbo, S.; Cabral, M.P.; Barbe, J.; Bou, G. Acinetobacter baumannii RecA protein in repair of DNA damage, antimicrobial resistance, general stress response, and virulence. J. Bacteriol. 2011, 193, 3740-3747. [CrossRef] [PubMed]

43. Chapartegui-Gonzalez, I.; Lazaro-Diez, M.; Bravo, Z.; Navas, J.; Icardo, J.M.; Ramos-Vivas, J. Acinetobacter baumannii maintains its virulence after long-time starvation. PLoS ONE 2018, 13, e0201961. [CrossRef] [PubMed]

44. Boll, J.M.; Tucker, A.T.; Klein, D.R.; Beltran, A.M.; Brodbelt, J.S.; Davies, B.W.; Trent, M.S. Reinforcing lipid A acylation on the cell surface of Acinetobacter baumannii promotes cationic antimicrobial peptide resistance and desiccation survival. mBio 2015, 6, e00478-15. [CrossRef] [PubMed]

45. Roca, I.; Espinal, P.; Vila-Farres, X.; Vila, J. The Acinetobacter baumannii oxymoron: Commensal hospital dweller turned pan-drug-resistant menace. Front. Microbiol. 2012, 3, 148. [CrossRef] [PubMed]

46. Gaddy, J.A.; Actis, L.A. Regulation of Acinetobacter baumannii biofilm formation. Future Microbiol. 2009, 4, 273-278. [CrossRef]

47. Thompson, M.G.; Black, C.C.; Pavlicek, R.L.; Honnold, C.L.; Wise, M.C.; Alamneh, Y.A.; Moon, J.K.; Kessler, J.L.; Si, Y.; Williams, R.; et al. Validation of a novel murine wound model of Acinetobacter baumannii infection. Antimicrob. Agents Chemother. 2014, 58, 1332-1342. [CrossRef]

48. Greene, C.; Vadlamudi, G.; Newton, D.; Foxman, B.; Xi, C. The influence of biofilm formation and multidrug resistance on environmental survival of clinical and environmental isolates of Acinetobacter baumannii. Am. J. Infect. Control 2016, 44, e65-e71. [CrossRef]

49. Wood, C.R.; Ohneck, E.J.; Edelmann, R.E.; Actis, L.A. A light-regulated type I pilus contributes to Acinetobacter baumannii biofilm, motility, and virulence functions. Infect. Immun. 2018, 86, e0442-18. [CrossRef]

50. Hassan, K.A.; Jackson, S.M.; Penesyan, A.; Patching, S.G.; Tetu, S.G.; Eijkelkamp, B.A.; Brown, M.H.; Henderson, P.J.; Paulsen, I.T. Transcriptomic and biochemical analyses identify a family of chlorhexidine efflux proteins. Proc. Natl. Acad. Sci. USA 2013, 110, 20254-20259. [CrossRef]

51. Lee, C.R.; Lee, J.H.; Park, M.; Park, K.S.; Bae, I.K.; Kim, Y.B.; Cha, C.J.; Jeong, B.C.; Lee, S.H. Biology of Acinetobacter baumannii: Pathogenesis, antibiotic resistance mechanisms, and prospective treatment options. Front. Cell Infect. Microbiol. 2017, 7, 55. [CrossRef]

52. Antunes, L.C.; Visca, P.; Towner, K.J. Acinetobacter baumannii: Evolution of a global pathogen. Pathog. Dis. 2014, 71, 292-301. [CrossRef] [PubMed]

53. Weber, B.S.; Harding, C.M.; Feldman, M.F. Pathogenic Acinetobacter: From the cell surface to infinity and beyond. J. Bacteriol. 2015, 198, 880-887. [CrossRef] [PubMed] 
54. Russo, T.A.; Luke, N.R.; Beanan, J.M.; Olson, R.; Sauberan, S.L.; MacDonald, U.; Schultz, L.W.; Umland, T.C.; Campagnari, A.A. The K1 capsular polysaccharide of Acinetobacter baumannii strain 307-0294 is a major virulence factor. Infect. Immun. 2010, 78, 3993-4000. [CrossRef] [PubMed]

55. Singh, J.K.; Adams, F.G.; Brown, M.H. Diversity and function of capsular polysaccharide in Acinetobacter baumannii. Front. Microbiol. 2018, 9, 3301. [CrossRef] [PubMed]

56. Niu, T.; Guo, L.; Luo, Q.; Zhou, K.; Yu, W.; Chen, Y.; Huang, C.; Xiao, Y. Wza gene knockout decreases Acinetobacter baumannii virulence and affects Wzy-dependent capsular polysaccharide synthesis. Virulence 2020, 11, 1-13. [CrossRef] [PubMed]

57. Chin, C.Y.; Tipton, K.A.; Farokhyfar, M.; Burd, E.M.; Weiss, D.S.; Rather, P.N. A high-frequency phenotypic switch links bacterial virulence and environmental survival in Acinetobacter baumannii. Nat. Microbiol. 2018, 3, 563-569. [CrossRef]

58. Cress, B.F.; Englaender, J.A.; He, W.; Kasper, D.; Linhardt, R.J.; Koffas, M.A. Masquerading microbial pathogens: Capsular polysaccharides mimic host-tissue molecules. FEMS Microbiol. Rev. 2014, 38, 660-697. [CrossRef]

59. Tolmasky, M.E.; Staneloni, R.J.; Leloir, L.F. Lipid-bound saccharides in Rhizobium meliloti. J. Biol. Chem. 1982, 257, 6751-6757.

60. Tolmasky, M.E.; Staneloni, R.J.; Ugalde, R.A.; Leloir, L.F. Lipid-bound sugars in Rhizobium meliloti. Arch. Biochem. Biophys. 1980, 203, 358-364. [CrossRef]

61. Gonzalez, J.E.; Semino, C.E.; Wang, L.X.; Castellano-Torres, L.E.; Walker, G.C. Biosynthetic control of molecular weight in the polymerization of the octasaccharide subunits of succinoglycan, a symbiotically important exopolysaccharide of Rhizobium meliloti. Proc. Natl. Acad. Sci. USA 1998, 95, 13477-13482. [CrossRef]

62. Ielpi, L.; Couso, R.O.; Dankert, M.A. Sequential assembly and polymerization of the polyprenol-linked pentasaccharide repeating unit of the xanthan polysaccharide in Xanthomonas campestris. J. Bacteriol. 1993, 175, 2490-2500. [CrossRef] [PubMed]

63. Hug, I.; Feldman, M.F. Analogies and homologies in lipopolysaccharide and glycoprotein biosynthesis in bacteria. Glycobiology 2011, 21, 138-151. [CrossRef] [PubMed]

64. Lees-Miller, R.G.; Iwashkiw, J.A.; Scott, N.E.; Seper, A.; Vinogradov, E.; Schild, S.; Feldman, M.F. A common pathway for O-linked protein-glycosylation and synthesis of capsule in Acinetobacter baumannii. Mol. Microbiol. 2013, 89, 816-830. [CrossRef] [PubMed]

65. Schmid, J.; Sieber, V.; Rehm, B. Bacterial exopolysaccharides: Biosynthesis pathways and engineering strategies. Front. Microbiol 2015, 6, 496. [CrossRef]

66. Staneloni, R.J.; Tolmasky, M.E.; Leloir, L.F. Lipid-bound saccharides containing glucose and galactose in Agrobacterium tumefaciens. J. Gen. Microbiol. 1984, 130, 869-879. [CrossRef]

67. Low, K.E.; Howell, P.L. Gram-negative synthase-dependent exopolysaccharide biosynthetic machines. Curr. Opin. Struct. Biol. 2018, 53, 32-44. [CrossRef]

68. Choi, A.H.; Slamti, L.; Avci, F.Y.; Pier, G.B.; Maira-Litran, T. The pgaABCD locus of Acinetobacter baumannii encodes the production of poly-beta-1-6- $N$-acetylglucosamine, which is critical for biofilm formation. J. Bacteriol. 2009, 191, 5953-5963. [CrossRef]

69. Kenyon, J.J.; Nigro, S.J.; Hall, R.M. Variation in the OC locus of Acinetobacter baumannii genomes predicts extensive structural diversity in the lipooligosaccharide. PLoS ONE 2014, 9, e107833. [CrossRef]

70. Geisinger, E.; Huo, W.; Hernandez-Bird, J.; Isberg, R.R. Acinetobacter baumannii: Envelope determinants that control drug resistance, virulence, and surface variability. Annu. Rev. Microbiol. 2019, 73, 481-506. [CrossRef]

71. Pelletier, M.R.; Casella, L.G.; Jones, J.W.; Adams, M.D.; Zurawski, D.V.; Hazlett, K.R.; Doi, Y.; Ernst, R.K. Unique structural modifications are present in the lipopolysaccharide from colistin-resistant strains of Acinetobacter baumannii. Antimicrob. Agents Chemother. 2013, 57, 4831-4840. [CrossRef]

72. Arroyo, L.A.; Herrera, C.M.; Fernandez, L.; Hankins, J.V.; Trent, M.S.; Hancock, R.E. The pmrCAB operon mediates polymyxin resistance in Acinetobacter baumannii ATCC 17978 and clinical isolates through phosphoethanolamine modification of lipid A. Antimicrob. Agents Chemother. 2011, 55, 3743-3751. [CrossRef] [PubMed]

73. Snitkin, E.S.; Zelazny, A.M.; Gupta, J.; Program, N.C.S.; Palmore, T.N.; Murray, P.R.; Segre, J.A. Genomic insights into the fate of colistin resistance and Acinetobacter baumannii during patient treatment. Genome Res. 2013, 23, 1155-1162. [CrossRef] [PubMed] 
74. Beceiro, A.; Llobet, E.; Aranda, J.; Bengoechea, J.A.; Doumith, M.; Hornsey, M.; Dhanji, H.; Chart, H.; Bou, G.; Livermore, D.M.; et al. Phosphoethanolamine modification of lipid A in colistin-resistant variants of Acinetobacter baumannii mediated by the pmrAB two-component regulatory system. Antimicrob. Agents Chemother. 2011, 55, 3370-3379. [CrossRef] [PubMed]

75. Iwashkiw, J.A.; Seper, A.; Weber, B.S.; Scott, N.E.; Vinogradov, E.; Stratilo, C.; Reiz, B.; Cordwell, S.J.; Whittal, R.; Schild, S.; et al. Identification of a general O-linked protein glycosylation system in Acinetobacter baumannii and its role in virulence and biofilm formation. PLoS Pathog. 2012, 8, e1002758. [CrossRef] [PubMed]

76. May, H.C.; Yu, J.J.; Zhang, H.; Wang, Y.; Cap, A.P.; Chambers, J.P.; Guentzel, M.N.; Arulanandam, B.P. Thioredoxin-A is a virulence factor and mediator of the type IV pilus system in Acinetobacter baumannii. PLoS ONE 2019, 14, e0218505. [CrossRef]

77. Elhosseiny, N.M.; Elhezawy, N.B.; Attia, A.S. Comparative proteomics analyses of Acinetobacter baumannii strains ATCC 17978 and AB5075 reveal the differential role of type II secretion system secretomes in lung colonization and ciprofloxacin resistance. Microb. Pathog. 2019, 128, 20-27. [CrossRef]

78. Harding, C.M.; Kinsella, R.L.; Palmer, L.D.; Skaar, E.P.; Feldman, M.F. Medically relevant Acinetobacter species require a type II secretion system and specific membrane-associated chaperones for the export of multiple substrates and full virulence. PLoS Pathog. 2016, 12, e1005391. [CrossRef]

79. Lopez, J.; Ly, P.M.; Feldman, M.F. The tip of the VgrG spike Is essential to functional type VI secretion system assembly in Acinetobacter baumannii. mBio 2020, 11, e02761-19. [CrossRef]

80. Repizo, G.D.; Gagne, S.; Foucault-Grunenwald, M.L.; Borges, V.; Charpentier, X.; Limansky, A.S.; Gomes, J.P.; Viale, A.M.; Salcedo, S.P. Differential role of the T6SS in Acinetobacter baumannii virulence. PLoS ONE 2015, 10, e0138265. [CrossRef]

81. Wang, J.; Zhou, Z.; He, F.; Ruan, Z.; Jiang, Y.; Hua, X.; Yu, Y. The role of the type VI secretion system vgrG gene in the virulence and antimicrobial resistance of Acinetobacter baumannii ATCC 19606. PLoS ONE 2018, 13, e0192288. [CrossRef]

82. Hesse, L.E.; Lonergan, Z.R.; Beavers, W.N.; Skaar, E.P. The Acinetobacter baumannii Znu system overcomes host-imposed nutrient zinc limitation. Infect. Immun. 2019, 87, e00746-19. [CrossRef] [PubMed]

83. Mortensen, B.L.; Skaar, E.P. The contribution of nutrient metal acquisition and metabolism to Acinetobacter baumannii survival within the host. Front. Cell Infect. Microbiol. 2013, 3, 95. [CrossRef] [PubMed]

84. Green, E.R.; Juttukonda, L.J.; Skaar, E.P. The manganese-responsive transcriptional regulator MumR protects Acinetobacter baumannii from oxidative stress. Infect. Immun. 2019, 88, e00762-19. [CrossRef] [PubMed]

85. Ramirez, M.S.; Penwell, W.F.; Traglia, G.M.; Zimbler, D.L.; Gaddy, J.A.; Nikolaidis, N.; Arivett, B.A.; Adams, M.D.; Bonomo, R.A.; Actis, L.A.; et al. Identification of potential virulence factors in the model strain Acinetobacter baumannii A118. Front. Microbiol. 2019, 10, 1599. [CrossRef] [PubMed]

86. Penwell, W.F.; Actis, L.A. Isolation and characterization of the acinetobactin and baumannoferrin siderophores produced by Acinetobacter baumannii. Methods Mol. Biol. 2019, 1946, 259-270. [PubMed]

87. Penwell, W.F.; Arivett, B.A.; Actis, L.A. The Acinetobacter baumannii entA gene located outside the acinetobactin cluster is critical for siderophore production, iron acquisition and virulence. PLoS ONE 2012, 7, e36493. [CrossRef]

88. Antunes, L.C.; Imperi, F.; Towner, K.J.; Visca, P. Genome-assisted identification of putative iron-utilization genes in Acinetobacter baumannii and their distribution among a genotypically diverse collection of clinical isolates. Res. Microbiol. 2011, 162, 279-284. [CrossRef]

89. Proschak, A.; Lubuta, P.; Grun, P.; Lohr, F.; Wilharm, G.; De Berardinis, V.; Bode, H.B. Structure and biosynthesis of fimsbactins A-F, siderophores from Acinetobacter baumannii and Acinetobacter baylyi. Chembiochem 2013, 14, 633-638. [CrossRef]

90. Juttukonda, L.J.; Chazin, W.J.; Skaar, E.P. Acinetobacter baumannii coordinates urea metabolism with metal import to resist host-mediated metal limitation. mBio 2016, 7, e01475-e01486. [CrossRef]

91. Crosa, J.H.; Walsh, C.T. Genetics and assembly line enzymology of siderophore biosynthesis in bacteria. Microbiol. Mol. Biol. Rev. 2002, 66, 223-249. [CrossRef]

92. Wooldridge, K.G.; Williams, P.H. Iron uptake mechanisms of pathogenic bacteria. FEMS Microbiol. Rev. 1993, 12, 325-348. [CrossRef] [PubMed]

93. Tolmasky, M.E.; Crosa, J.H. Regulation of plasmid-mediated iron transport and virulence in Vibrio anguillarum. Biol. Met. 1991, 4, 33-35. [CrossRef] [PubMed] 
94. Di Lorenzo, M.; Stork, M. Plasmid-encoded iron uptake systems. Microbiol. Spectr. 2014, 2, PLAS-0030-2014. [CrossRef] [PubMed]

95. Parrow, N.L.; Fleming, R.E.; Minnick, M.F. Sequestration and scavenging of iron in infection. Infect. Immun. 2013, 81, 3503-3514. [CrossRef] [PubMed]

96. Porcheron, G.; Garenaux, A.; Proulx, J.; Sabri, M.; Dozois, C.M. Iron, copper, zinc, and manganese transport and regulation in pathogenic Enterobacteria: Correlations between strains, site of infection and the relative importance of the different metal transport systems for virulence. Front. Cell Infect. Microbiol. 2013, 3, 90. [CrossRef]

97. Lau, C.K.; Krewulak, K.D.; Vogel, H.J. Bacterial ferrous iron transport: The Feo system. FEMS Microbiol. Rev. 2016, 40, 273-298. [CrossRef]

98. Alvarez-Fraga, L.; Vazquez-Ucha, J.C.; Martinez-Guitian, M.; Vallejo, J.A.; Bou, G.; Beceiro, A.; Poza, M. Pneumonia infection in mice reveals the involvement of the feoA gene in the pathogenesis of Acinetobacter baumannii. Virulence 2018, 9, 496-509. [CrossRef]

99. de Leseleuc, L.; Harris, G.; KuoLee, R.; Xu, H.H.; Chen, W. Serum resistance, gallium nitrate tolerance and extrapulmonary dissemination are linked to heme consumption in a bacteremic strain of Acinetobacter baumannii. Int. J. Med. Microbiol. 2014, 304, 360-369. [CrossRef]

100. Zimbler, D.L.; Penwell, W.F.; Gaddy, J.A.; Menke, S.M.; Tomaras, A.P.; Connerly, P.L.; Actis, L.A. Iron acquisition functions expressed by the human pathogen Acinetobacter baumannii. Biometals 2009, 22, $23-32$. [CrossRef]

101. Ramirez, M.S.; Adams, M.D.; Bonomo, R.A.; Centron, D.; Tolmasky, M.E. Genomic analysis of Acinetobacter baumannii A118 by comparison of optical maps: Identification of structures related to its susceptibility phenotype. Antimicrob. Agents Chemother. 2011, 55, 1520-1526. [CrossRef]

102. Dorsey, C.W.; Tomaras, A.P.; Connerly, P.L.; Tolmasky, M.E.; Crosa, J.H.; Actis, L.A. The siderophore-mediated iron acquisition systems of Acinetobacter baumannii ATCC 19606 and Vibrio anguillarum 775 are structurally and functionally related. Microbiology 2004, 150, 3657-3667. [CrossRef] [PubMed]

103. Bailey, D.C.; Bohac, T.J.; Shapiro, J.A.; Giblin, D.E.; Wencewicz, T.A.; Gulick, A.M. Crystal structure of the siderophore binding protein BauB bound to an unusual 2:1 complex between acinetobactin and ferric iron. Biochemistry 2018, 57, 6653-6661. [CrossRef] [PubMed]

104. Di Lorenzo, M.; Poppelaars, S.; Stork, M.; Nagasawa, M.; Tolmasky, M.E.; Crosa, J.H. A nonribosomal peptide synthetase with a novel domain organization is essential for siderophore biosynthesis in Vibrio anguillarum. J. Bacteriol. 2004, 186, 7327-7336. [CrossRef] [PubMed]

105. Actis, L.A.; Fish, W.; Crosa, J.H.; Kellerman, K.; Ellenberger, S.R.; Hauser, F.M.; Sanders-Loehr, J. Characterization of anguibactin, a novel siderophore from Vibrio anguillarum 775(pJM1). J. Bacteriol. 1986, 167, 57-65. [CrossRef]

106. Actis, L.; Tolmasky, M.E.; Crosa, J.H. Vibriosis. In Fish Diseases and Disorders; Woo, P.T., Bruno, D.W., Eds.; CAB International: New York, NY, USA, 1999; Volume 3, pp. 523-557.

107. Bohac, T.J.; Fang, L.; Giblin, D.E.; Wencewicz, T.A. Fimsbactin and acinetobactin compete for the periplasmic siderophore binding protein BauB in pathogenic Acinetobacter baumannii. ACS Chem. Biol. 2019, 14, 674-687. [CrossRef]

108. Penwell, W.F.; DeGrace, N.; Tentarelli, S.; Gauthier, L.; Gilbert, C.M.; Arivett, B.A.; Miller, A.A.; Durand-Reville, T.F.; Joubran, C.; Actis, L.A. Discovery and characterization of new hydroxamate siderophores, baumannoferrin A and B, produced by Acinetobacter baumannii. Chembiochem 2015, 16, 1896-1904. [CrossRef]

109. Morris, F.C.; Dexter, C.; Kostoulias, X.; Uddin, M.I.; Peleg, A.Y. The mechanisms of disease caused by Acinetobacter baumannii. Front. Microbiol. 2019, 10, 1601. [CrossRef]

110. Li, F.J.; Starrs, L.; Burgio, G. Tug of war between Acinetobacter baumannii and host immune responses. Pathog. Dis. 2018, 76. [CrossRef]

111. Kroger, C.; Kary, S.C.; Schauer, K.; Cameron, A.D. Genetic regulation of virulence and antibiotic resistance in Acinetobacter baumannii. Genes (Basel) 2016, 8, 12. [CrossRef]

112. Kareem, S.M.; Al-Kadmy, I.M.S.; Al-Kaabi, M.H.; Aziz, S.N.; Ahmad, M. Acinetobacter baumannii virulence is enhanced by the combined presence of virulence factors genes phospholipase C ( $p l c N)$ and elastase (lasB). Microb. Pathog. 2017, 110, 568-572. [CrossRef] 
113. Fiester, S.E.; Arivett, B.A.; Schmidt, R.E.; Beckett, A.C.; Ticak, T.; Carrier, M.V.; Ghosh, R.; Ohneck, E.J.; Metz, M.L.; Sellin Jeffries, M.K.; et al. Iron-regulated phospholipase C activity contributes to the cytolytic activity and virulence of Acinetobacter baumannii. PLoS ONE 2016, 11, e0167068. [CrossRef] [PubMed]

114. Bentancor, L.V.; Routray, A.; Bozkurt-Guzel, C.; Camacho-Peiro, A.; Pier, G.B.; Maira-Litran, T. Evaluation of the trimeric autotransporter Ata as a vaccine candidate against Acinetobacter baumannii infections. Infect. Immun. 2012, 80, 3381-3388. [CrossRef] [PubMed]

115. Chatterjee, S.; Mondal, A.; Mitra, S.; Basu, S. Acinetobacter baumannii transfers the blaNDM-1 gene via outer membrane vesicles. J. Antimicrob. Chemother. 2017, 72, 2201-2207. [CrossRef] [PubMed]

116. Kim, S.Y.; Kim, M.H.; Kim, S.I.; Son, J.H.; Kim, S.; Lee, Y.C.; Shin, M.; Oh, M.H.; Lee, J.C. The sensor kinase BfmS controls production of outer membrane vesicles in Acinetobacter baumannii. BMC Microbiol. 2019, 19, 301. [CrossRef]

117. Koenigs, A.; Stahl, J.; Averhoff, B.; Gottig, S.; Wichelhaus, T.A.; Wallich, R.; Zipfel, P.F.; Kraiczy, P. CipA of Acinetobacter baumannii is a novel plasminogen binding and complement inhibitory protein. J. Infect. Dis. 2016, 213, 1388-1399. [CrossRef]

118. Koenigs, A.; Zipfel, P.F.; Kraiczy, P. Translation elongation factor Tuf of Acinetobacter baumannii is a plasminogen-binding protein. PLOS ONE 2015, 10, e0134418.

119. Gebhardt, M.J.; Shuman, H.A. GigA and GigB are master regulators of antibiotic resistance, stress responses, and virulence in Acinetobacter baumannii. J. Bacteriol. 2017, 199, e00066-17. [CrossRef]

120. Gebhardt, M.J.; Gallagher, L.A.; Jacobson, R.K.; Usacheva, E.A.; Peterson, L.R.; Zurawski, D.V.; Shuman, H.A. Joint transcriptional control of virulence and resistance to antibiotic and environmental stress in Acinetobacter baumannii. mBio 2015, 6, e01660-15. [CrossRef]

121. Cerqueira, G.M.; Kostoulias, X.; Khoo, C.; Aibinu, I.; Qu, Y.; Traven, A.; Peleg, A.Y. A global virulence regulator in Acinetobacter baumannii and its control of the phenylacetic acid catabolic pathway. J. Infect. Dis. 2014, 210, 46-55. [CrossRef]

122. Lin, F.; Xu, Y.; Chang, Y.; Liu, C.; Jia, X.; Ling, B. Molecular characterization of reduced susceptibility to biocides in clinical isolates of Acinetobacter baumannii. Front. Microbiol. 2017, 8, 1836. [CrossRef]

123. Darwish Alipour Astaneh, S.; Rasooli, I.; Mousavi Gargari, S.L. Filamentous hemagglutinin adhesin FhaB limits A.baumannii biofilm formation. Front. Biosci. 2017, 9, 266-275.

124. Tipton, K.A.; Rather, P.N. An ompR-envZ two-component system ortholog regulates phase variation, osmotic tolerance, motility, and virulence in Acinetobacter baumannii strain AB5075. J. Bacteriol. 2017, 199, e00705-e00716. [CrossRef] [PubMed]

125. Camarena, L.; Bruno, V.; Euskirchen, G.; Poggio, S.; Snyder, M. Molecular mechanisms of ethanol-induced pathogenesis revealed by RNA-sequencing. PLoS Pathog. 2010, 6, e1000834. [CrossRef] [PubMed]

126. Nwugo, C.C.; Arivett, B.A.; Zimbler, D.L.; Gaddy, J.A.; Richards, A.M.; Actis, L.A. Effect of ethanol on differential protein production and expression of potential virulence functions in the opportunistic pathogen Acinetobacter baumannii. PLoS ONE 2012, 7, e51936. [CrossRef]

127. Szabo, G.; Verma, B.; Catalano, D. Selective inhibition of antigen-specific T lymphocyte proliferation by acute ethanol exposure: The role of impaired monocyte antigen presentation capacity and mediator production. J. Leukoc. Biol. 1993, 54, 534-544. [CrossRef]

128. Szabo, G.; Dolganiuc, A.; Mandrekar, P.; White, B. Inhibition of antigen-presenting cell functions by alcohol: Implications for hepatitis C virus infection. Alcohol 2004, 33, 241-249. [CrossRef]

129. Achur, R.N.; Freeman, W.M.; Vrana, K.E. Circulating cytokines as biomarkers of alcohol abuse and alcoholism. J. Neuroimmune Pharmacol. 2010, 5, 83-91. [CrossRef]

130. Gallucci, R.M.; Pfister, L.J.; Meadows, G.G. Effects of ethanol consumption on enriched natural killer cells from C57BL/6 mice. Alcohol. Clin. Exp. Res. 1994, 18, 625-631. [CrossRef]

131. Spinozzi, F.; Agea, E.; Bassotti, G.; Belia, S.; Rondoni, F.; Broccucci, L.; Solinas, A.; Gerli, R.; Bertotto, A. Ethanol-specific impairment of T-lymphocyte activation is caused by a transitory block in signal-transduction pathways. Gastroenterology 1993, 105, 1490-1501. [CrossRef]

132. Gandhi, J.A.; Ekhar, V.V.; Asplund, M.B.; Abdulkareem, A.F.; Ahmadi, M.; Coelho, C.; Martinez, L.R. Alcohol enhances Acinetobacter baumannii-associated pneumonia and systemic dissemination by impairing neutrophil antimicrobial activity in a murine model of infection. PLoS ONE 2014, 9, e95707. [CrossRef]

133. Asplund, M.B.; Coelho, C.; Cordero, R.J.; Martinez, L.R. Alcohol impairs J774.16 macrophage-like cell antimicrobial functions in Acinetobacter baumannii infection. Virulence 2013, 4, 467-472. [CrossRef] [PubMed] 
134. Smith, M.G.; Des Etages, S.G.; Snyder, M. Microbial synergy via an ethanol-triggered pathway. Mol. Cell. Biol. 2004, 24, 3874-3884. [CrossRef] [PubMed]

135. Thomson, J.M.; Bonomo, R.A. The threat of antibiotic resistance in Gram-negative pathogenic bacteria: Beta-lactams in peril! Curr. Opin. Microbiol. 2005, 8, 518-524. [CrossRef] [PubMed]

136. Mohd Sazlly Lim, S.; Zainal Abidin, A.; Liew, S.M.; Roberts, J.A.; Sime, F.B. The global prevalence of multidrug-resistance among Acinetobacter baumannii causing hospital-acquired and ventilator-associated pneumonia and its associated mortality: A systematic review and meta-analysis. J. Infect. 2019, 79, 593-600. [CrossRef]

137. Butler, D.A.; Biagi, M.; Tan, X.; Qasmieh, S.; Bulman, Z.P.; Wenzler, E. Multidrug resistant Acinetobacter baumannii: Resistance by any other name would still be hard to treat. Curr. Infect. Dis. Rep. 2019, 21, 46. [CrossRef]

138. Nowak, P.; Paluchowska, P. Acinetobacter baumannii: Biology and drug resistance - role of carbapenemases. Folia Histochem. Cytobiol. 2016, 54, 61-74. [CrossRef]

139. Paterson, D.L.; Bonomo, R.A. Multidrug-resistant gram-negative pathogens: The urgent need for 'old' polymyxins. Adv. Exp. Med. Biol. 2019, 1145, 9-13.

140. Perez, F.; Hujer, A.M.; Hujer, K.M.; Decker, B.K.; Rather, P.N.; Bonomo, R.A. Global challenge of multidrug-resistant Acinetobacter baumannii. Antimicrob. Agents Chemother. 2007, 51, 3471-3484. [CrossRef]

141. Ramirez, M.S.; Nikolaidis, N.; Tolmasky, M.E. Rise and dissemination of aminoglycoside resistance: The aac(6')-Ib paradigm. Front. Microbiol. 2013, 4, 121. [CrossRef]

142. Ramirez, M.S.; Tolmasky, M.E. Aminoglycoside modifying enzymes. Drug Resist. Updat 2010, 13, $151-171$. [CrossRef]

143. Bonomo, R.A.; Szabo, D. Mechanisms of multidrug resistance in Acinetobacter species and Pseudomonas aeruginosa. Clin. Infect. Dis. 2006, 43 (Suppl. 2), S49-S56. [CrossRef] [PubMed]

144. Manchanda, V.; Sanchaita, S.; Singh, N. Multidrug resistant Acinetobacter. J. Glob. Infect. Dis. 2010, 2, $291-304$. [CrossRef] [PubMed]

145. Perez, F.; El Chakhtoura, N.G.; Yasmin, M.; Bonomo, R.A. Polymyxins: To combine or not to combine? Antibiotics (Basel) 2019, 8, 38. [CrossRef] [PubMed]

146. Shin, B.; Park, W. Antibiotic resistance of pathogenic Acinetobacter species and emerging combination therapy. J. Microbiol 2017, 55, 837-849. [CrossRef]

147. Nasr, P. Genetics, epidemiology, and clinical manifestations of multidrug-resistant Acinetobacter baumannii. J. Hosp. Infect. 2020, 104, 4-11. [CrossRef]

148. Hou, P.F.; Chen, X.Y.; Yan, G.F.; Wang, Y.P.; Ying, C.M. Study of the correlation of imipenem resistance with efflux pumps AdeABC, AdeIJK, AdeDE and AbeM in clinical isolates of Acinetobacter baumannii. Chemotherapy 2012, 58, 152-158. [CrossRef]

149. Xu, C.; Bilya, S.R.; Xu, W. adeABC efflux gene in Acinetobacter baumannii. New Microbes New Infect. 2019, 30, 100549. [CrossRef]

150. Hamidian, M.; Nigro, S.J. Emergence, molecular mechanisms and global spread of carbapenem-resistant Acinetobacter baumannii. Microb Genom 2019, 5, e000306. [CrossRef]

151. Zhang, Y.; Li, Z.; He, X.; Ding, F.; Wu, W.; Luo, Y.; Fan, B.; Cao, H. Overproduction of efflux pumps caused reduced susceptibility to carbapenem under consecutive imipenem-selected stress in Acinetobacter baumannii. Infect Drug Resist 2017, 11, 457-467. [CrossRef]

152. Rumbo, C.; Gato, E.; Lopez, M.; Ruiz de Alegria, C.; Fernandez-Cuenca, F.; Martinez-Martinez, L.; Vila, J.; Pachon, J.; Cisneros, J.M.; Rodriguez-Bano, J.; et al. Contribution of efflux pumps, porins, and beta-lactamases to multidrug resistance in clinical isolates of Acinetobacter baumannii. Antimicrob. Agents Chemother. 2013, 57, 5247-5257. [CrossRef]

153. Poirel, L.; Nordmann, P. Carbapenem resistance in Acinetobacter baumannii: Mechanisms and epidemiology. Clin. Microbiol. Infect. 2006, 12, 826-836. [CrossRef] [PubMed]

154. Mussi, M.A.; Limansky, A.S.; Viale, A.M. Acquisition of resistance to carbapenems in multidrug-resistant clinical strains of Acinetobacter baumannii: Natural insertional inactivation of a gene encoding a member of a novel family of beta-barrel outer membrane proteins. Antimicrob. Agents Chemother. 2005, 49, 1432-1440. [CrossRef] [PubMed]

155. del Mar Tomas, M.; Beceiro, A.; Perez, A.; Velasco, D.; Moure, R.; Villanueva, R.; Martinez-Beltran, J.; Bou, G. Cloning and functional analysis of the gene encoding the 33- to 36-kilodalton outer membrane protein 
associated with carbapenem resistance in Acinetobacter baumannii. Antimicrob. Agents Chemother. 2005, 49, 5172-5175. [CrossRef] [PubMed]

156. Vashist, J.; Tiwari, V.; Das, R.; Kapil, A.; Rajeswari, M.R. Analysis of penicillin-binding proteins (PBPs) in carbapenem resistant Acinetobacter baumannii. Indian J. Med. Res. 2011, 133, 332-338.

157. Fernandez-Cuenca, F.; Martinez-Martinez, L.; Conejo, M.C.; Ayala, J.A.; Perea, E.J.; Pascual, A. Relationship between beta-lactamase production, outer membrane protein and penicillin-binding protein profiles on the activity of carbapenems against clinical isolates of Acinetobacter baumannii. J. Antimicrob. Chemother. 2003, 51, 565-574. [CrossRef]

158. Bush, K. Past and present perspectives on beta-lactamases. Antimicrob. Agents Chemother. 2018, 62, e01076-18. [CrossRef]

159. Bonomo, R.A. beta-lactamases: A focus on current challenges. Cold Spring Harb. Perspect. Med. 2017, 7, a025239. [CrossRef]

160. Bush, K.; Bradford, P.A. Epidemiology of beta-lactamase-producing pathogens. Clin. Microbiol. Rev. 2020, 33, e00047-19. [CrossRef]

161. Bush, K.; Jacoby, G.A. Updated functional classification of beta-lactamases. Antimicrob. Agents Chemother. 2010, 54, 969-976. [CrossRef]

162. Ambler, R.P. The structure of beta-lactamases. Philos. Trans. R. Soc. Lond. B Biol. Sci. 1980, 289, 321-331.

163. Evans, B.A.; Amyes, S.G. OXA beta-lactamases. Clin. Microbiol. Rev. 2014, 27, 241-263. [CrossRef] [PubMed]

164. Sykes, R.B.; Matthew, M. The beta-lactamases of gram-negative bacteria and their role in resistance to beta-lactam antibiotics. J. Antimicrob. Chemother. 1976, 2, 115-157. [CrossRef]

165. Medeiros, A.A.; Cohenford, M.; Jacoby, G.A. Five novel plasmid-determined beta-lactamases. Antimicrob. Agents Chemother. 1985, 27, 715-719. [CrossRef] [PubMed]

166. Tolmasky, M.E. Sequencing and expression of aadA, bla, and $\operatorname{tnpR}$ from the multiresistance transposon Tn1331. Plasmid 1990, 24, 218-226. [CrossRef]

167. Tolmasky, M.E.; Crosa, J.H. Genetic organization of antibiotic resistance genes (aac( $\left.6^{\prime}\right)-I b$, aadA, and oxa9) in the multiresistance transposon Tn1331. Plasmid 1993, 29, 31-40. [CrossRef] [PubMed]

168. Hall, L.M.; Livermore, D.M.; Gur, D.; Akova, M.; Akalin, H.E. OXA-11, an extended-spectrum variant of OXA-10 (PSE-2) beta-lactamase from Pseudomonas aeruginosa. Antimicrob. Agents Chemother. 1993, 37, 1637-1644. [CrossRef] [PubMed]

169. Queenan, A.M.; Bush, K. Carbapenemases: The versatile beta-lactamases. Clin. Microbiol. Rev. 2007, 20, 440-458. [CrossRef]

170. Donald, H.M.; Scaife, W.; Amyes, S.G.; Young, H.K. Sequence analysis of ARI-1, a novel OXA beta-lactamase, responsible for imipenem resistance in Acinetobacter baumannii 6B92. Antimicrob. Agents Chemother. 2000, 44, 196-199. [CrossRef]

171. Afzal-Shah, M.; Woodford, N.; Livermore, D.M. Characterization of OXA-25, OXA-26, and OXA-27, molecular class $\mathrm{D}$ beta-lactamases associated with carbapenem resistance in clinical isolates of Acinetobacter baumannii. Antimicrob. Agents Chemother. 2001, 45, 583-588. [CrossRef]

172. Kaitany, K.C.; Klinger, N.V.; June, C.M.; Ramey, M.E.; Bonomo, R.A.; Powers, R.A.; Leonard, D.A. Structures of the class D carbapenemases OXA-23 and OXA-146: Mechanistic basis of activity against carbapenems, extended-spectrum cephalosporins, and aztreonam. Antimicrob. Agents Chemother. 2013, 57, 4848-4855. [CrossRef]

173. Smith, C.A.; Antunes, N.T.; Stewart, N.K.; Toth, M.; Kumarasiri, M.; Chang, M.; Mobashery, S.; Vakulenko, S.B. Structural basis for carbapenemase activity of the OXA-23 beta-lactamase from Acinetobacter baumannii. Chem. Biol. 2013, 20, 1107-1115. [CrossRef] [PubMed]

174. Altschul, S.F.; Madden, T.L.; Schaffer, A.A.; Zhang, J.; Zhang, Z.; Miller, W.; Lipman, D.J. Gapped BLAST and PSI-BLAST: A new generation of protein database search programs. Nucleic Acids Res. 1997, 25, 3389-3402. [CrossRef] [PubMed]

175. Mugnier, P.D.; Poirel, L.; Naas, T.; Nordmann, P. Worldwide dissemination of the blaOXA-23 carbapenemase gene of Acinetobacter baumannii. Emerg. Infect. Dis. 2010, 16, 35-40. [CrossRef] [PubMed]

176. Poirel, L.; Figueiredo, S.; Cattoir, V.; Carattoli, A.; Nordmann, P. Acinetobacter radioresistens as a silent source of carbapenem resistance for Acinetobacter spp. Antimicrob. Agents Chemother. 2008, 52, 1252-1256. [CrossRef]

177. Nigro, S.J.; Hall, R.M. Structure and context of Acinetobacter transposons carrying the oxa23 carbapenemase gene. J. Antimicrob. Chemother. 2016, 71, 1135-1147. [CrossRef] 
178. Mugnier, P.D.; Poirel, L.; Nordmann, P. Functional analysis of insertion sequence ISAba1, responsible for genomic plasticity of Acinetobacter baumannii. J. Bacteriol. 2009, 191, 2414-2418. [CrossRef]

179. Chen, Y.; Gao, J.; Zhang, H.; Ying, C. Spread of the blaOXA-23-containing Tn2008 in carbapenem-resistant Acinetobacter baumannii isolates grouped in CC92 from China. Front. Microbiol. 2017, 8, 163. [CrossRef]

180. Hua, X.; Xu, Q.; Zhou, Z.; Ji, S.; Yu, Y. Relocation of Tn2009 and characterization of an ABGRI3-2 from re-sequenced genome sequence of Acinetobacter baumannii MDR-ZJ06. J. Antimicrob. Chemother. 2019, 74, 1153-1155. [CrossRef]

181. Linder, P.; Lasko, P.F.; Ashburner, M.; Leroy, P.; Nielsen, P.J.; Nishi, K.; Schnier, J.; Slonimski, P.P. Birth of the D-E-A-D box. Nature 1989, 337, 121-122. [CrossRef]

182. Bou, G.; Oliver, A.; Martinez-Beltran, J. OXA-24, a novel class D beta-lactamase with carbapenemase activity in an Acinetobacter baumannii clinical strain. Antimicrob. Agents Chemother. 2000, 44, 1556-1561. [CrossRef]

183. D'Andrea, M.M.; Giani, T.; D’Arezzo, S.; Capone, A.; Petrosillo, N.; Visca, P.; Luzzaro, F.; Rossolini, G.M. Characterization of pABVA01, a plasmid encoding the OXA-24 carbapenemase from Italian isolates of Acinetobacter baumannii. Antimicrob. Agents Chemother. 2009, 53, 3528-3533. [CrossRef] [PubMed]

184. Tian, G.B.; Adams-Haduch, J.M.; Bogdanovich, T.; Pasculle, A.W.; Quinn, J.P.; Wang, H.N.; Doi, Y. Identification of diverse OXA-40 group carbapenemases, including a novel variant, OXA-160, from Acinetobacter baumannii in Pennsylvania. Antimicrob. Agents Chemother. 2011, 55, 429-432. [CrossRef] [PubMed]

185. Merino, M.; Acosta, J.; Poza, M.; Sanz, F.; Beceiro, A.; Chaves, F.; Bou, G. OXA-24 carbapenemase gene flanked by XerC/XerD-like recombination sites in different plasmids from different Acinetobacter species isolated during a nosocomial outbreak. Antimicrob. Agents Chemother. 2010, 54, 2724-2727. [CrossRef] [PubMed]

186. Tran, T.; Andres, P.; Petroni, A.; Soler-Bistue, A.; Albornoz, E.; Zorreguieta, A.; Reyes-Lamothe, R.; Sherratt, D.J.; Corso, A.; Tolmasky, M.E. Small plasmids harboring qnrB19: A model for plasmid evolution mediated by site-specific recombination at oriT and Xer sites. Antimicrob. Agents Chemother. 2012, 56, 1821-1827. [CrossRef]

187. Zakharova, M.V.; Beletskaya, I.V.; Denjmukhametov, M.M.; Yurkova, T.V.; Semenova, L.M.; Shlyapnikov, M.G.; Solonin, A.S. Characterization of pECL18 and pKPN2: A proposed pathway for the evolution of two plasmids that carry identical genes for a Type II restriction-modification system. Mol Genet. Genomics 2002, 267, 171-178. [CrossRef] [PubMed]

188. Ramirez, M.S.; Traglia, G.M.; Lin, D.L.; Tran, T.; Tolmasky, M.E. Plasmid-mediated antibiotic resistance and virulence in Gram-negatives: The Klebsiella pneumoniae paradigm. Microbiology Spectr. 2014, 2, 1-15. [CrossRef]

189. Santillana, E.; Beceiro, A.; Bou, G.; Romero, A. Crystal structure of the carbapenemase OXA-24 reveals insights into the mechanism of carbapenem hydrolysis. Proc. Natl. Acad. Sci. USA 2007, 104, 5354-5359. [CrossRef]

190. Schneider, K.D.; Ortega, C.J.; Renck, N.A.; Bonomo, R.A.; Powers, R.A.; Leonard, D.A. Structures of the class D carbapenemase OXA-24 from Acinetobacter baumannii in complex with doripenem. J. Mol. Biol. 2011, 406, 583-594. [CrossRef]

191. Bou, G.; Santillana, E.; Sheri, A.; Beceiro, A.; Sampson, J.M.; Kalp, M.; Bethel, C.R.; Distler, A.M.; Drawz, S.M.; Pagadala, S.R.; et al. Design, synthesis, and crystal structures of 6-alkylidene-2'-substituted penicillanic acid sulfones as potent inhibitors of Acinetobacter baumannii OXA-24 carbapenemase. J. Am. Chem. Soc. 2010, 132, 13320-13331. [CrossRef]

192. Che, T.; Bonomo, R.A.; Shanmugam, S.; Bethel, C.R.; Pusztai-Carey, M.; Buynak, J.D.; Carey, P.R. Carboxylation and decarboxylation of active site Lys 84 controls the activity of OXA-24 beta-lactamase of Acinetobacter baumannii: Raman crystallographic and solution evidence. J. Am. Chem. Soc. 2012, 134, 11206-11215. [CrossRef]

193. Staude, M.W.; Leonard, D.A.; Peng, J.W. Expanded substrate activity of OXA-24/40 in carbapenem-resistant Acinetobacter baumannii involves enhanced binding loop flexibility. Biochemistry 2016, 55, 6535-6544. [CrossRef] [PubMed]

194. Brown, S.; Young, H.K.; Amyes, S.G. Characterisation of OXA-51, a novel class D carbapenemase found in genetically unrelated clinical strains of Acinetobacter baumannii from Argentina. Clin. Microbiol. Infect. 2005, 11, 15-23. [CrossRef] [PubMed] 
195. Merkier, A.K.; Centron, D. bla(OXA-51)-type beta-lactamase genes are ubiquitous and vary within a strain in Acinetobacter baumannii. Int. J. Antimicrob. Agents 2006, 28, 110-113. [CrossRef] [PubMed]

196. Turton, J.F.; Woodford, N.; Glover, J.; Yarde, S.; Kaufmann, M.E.; Pitt, T.L. Identification of Acinetobacter baumannii by detection of the blaOXA-51-like carbapenemase gene intrinsic to this species. J. Clin. Microbiol. 2006, 44, 2974-2976. [CrossRef]

197. Vijayakumar, S.; Biswas, I.; Veeraraghavan, B. Accurate identification of clinically important Acinetobacter spp.: An update. Future Sci. OA 2019, 5, FSO395. [CrossRef]

198. Chen, T.L.; Lee, Y.T.; Kuo, S.C.; Hsueh, P.R.; Chang, F.Y.; Siu, L.K.; Ko, W.C.; Fung, C.P. Emergence and distribution of plasmids bearing the blaOXA-51-like gene with an upstream ISAba1 in carbapenem-resistant Acinetobacter baumannii isolates in Taiwan. Antimicrob. Agents Chemother. 2010, 54, 4575-4581. [CrossRef]

199. Lee, Y.T.; Kuo, S.C.; Chiang, M.C.; Yang, S.P.; Chen, C.P.; Chen, T.L.; Fung, C.P. Emergence of carbapenem-resistant non-baumannii species of Acinetobacter harboring a blaOXA-51-like gene that is intrinsic to A. baumannii. Antimicrob. Agents Chemother. 2012, 56, 1124-1127. [CrossRef]

200. Ahmadi, A.; Salimizand, H. Delayed identification of Acinetobacter baumannii during an outbreak owing to disrupted blaOXA-51-like by ISAba19. Int. J. Antimicrob. Agents 2017, 50, 119-122. [CrossRef]

201. Tiwari, V.; Moganty, R.R. Conformational stability of OXA-51 beta-lactamase explains its role in carbapenem resistance of Acinetobacter baumannii. J. Biomol. Struct. Dyn. 2014, 32, 1406-1420. [CrossRef]

202. Wong, M.H.; Chan, B.K.; Chan, E.W.; Chen, S. Over-expression of ISAba1-linked intrinsic and exogenously acquired OXA type carbapenem-hydrolyzing-class D-beta-lactamase-encoding genes is key mechanism underlying carbapenem resistance in Acinetobacter baumannii. Front. Microbiol. 2019, 10, 2809. [CrossRef]

203. Nigro, S.J.; Hall, R.M. Does the intrinsic oxaAb (blaOXA-51-like) gene of Acinetobacter baumannii confer resistance to carbapenems when activated by ISAba1? J. Antimicrob. Chemother. 2018, 73, 3518-3520. [CrossRef] [PubMed]

204. Figueiredo, S.; Poirel, L.; Croize, J.; Recule, C.; Nordmann, P. In vivo selection of reduced susceptibility to carbapenems in Acinetobacter baumannii related to ISAba1-mediated overexpression of the natural bla(OXA-66) oxacillinase gene. Antimicrob. Agents Chemother. 2009, 53, 2657-2659. [CrossRef] [PubMed]

205. Turton, J.F.; Ward, M.E.; Woodford, N.; Kaufmann, M.E.; Pike, R.; Livermore, D.M.; Pitt, T.L. The role of ISAba1 in expression of OXA carbapenemase genes in Acinetobacter baumannii. FEMS Microbiol. Lett. 2006, 258, 72-77. [CrossRef] [PubMed]

206. Hu, W.S.; Yao, S.M.; Fung, C.P.; Hsieh, Y.P.; Liu, C.P.; Lin, J.F. An OXA-66/OXA-51-like carbapenemase and possibly an efflux pump are associated with resistance to imipenem in Acinetobacter baumannii. Antimicrob. Agents Chemother. 2007, 51, 3844-3852. [CrossRef] [PubMed]

207. June, C.M.; Muckenthaler, T.J.; Schroder, E.C.; Klamer, Z.L.; Wawrzak, Z.; Powers, R.A.; Szarecka, A.; Leonard, D.A. The structure of a doripenem-bound OXA-51 class D beta-lactamase variant with enhanced carbapenemase activity. Protein Sci. 2016, 25, 2152-2163. [CrossRef] [PubMed]

208. Mitchell, J.M.; Leonard, D.A. Common clinical substitutions enhance the carbapenemase activity of OXA-51-like class D beta-lactamases from Acinetobacter spp. Antimicrob. Agents Chemother. 2014, 58, 7015-7016. [CrossRef]

209. Schroder, E.C.; Klamer, Z.L.; Saral, A.; Sugg, K.A.; June, C.M.; Wymore, T.; Szarecka, A.; Leonard, D.A. Clinical variants of the native class $\mathrm{D}$ beta-lactamase of Acinetobacter baumannii pose an emerging threat through Increased hydrolytic activity against carbapenems. Antimicrob. Agents Chemother. 2016, 60, 6155-6164. [CrossRef]

210. Li, H.; Liu, F.; Zhang, Y.; Wang, X.; Zhao, C.; Chen, H.; Zhang, F.; Zhu, B.; Hu, Y.; Wang, H. Evolution of carbapenem-resistant Acinetobacter baumannii revealed through whole-genome sequencing and comparative genomic analysis. Antimicrob. Agents Chemother. 2015, 59, 1168-1176. [CrossRef]

211. Evans, B.A.; Brown, S.; Hamouda, A.; Findlay, J.; Amyes, S.G. Eleven novel OXA-51-like enzymes from clinical isolates of Acinetobacter baumannii. Clin. Microbiol. Infect. 2007, 13, 1137-1138. [CrossRef]

212. Tsakris, A.; Ikonomidis, A.; Spanakis, N.; Pournaras, S.; Bethimouti, K. Identification of a novel bla(OXA-51) variant, bla(OXA-92), from a clinical isolate of Acinetobacter baumannii. Clin. Microbiol. Infect. 2007, 13, 348-349. [CrossRef]

213. Smith, C.A.; Antunes, N.T.; Stewart, N.K.; Frase, H.; Toth, M.; Kantardjieff, K.A.; Vakulenko, S. Structural basis for enhancement of carbapenemase activity in the OXA-51 family of class D beta-lactamases. ACS Chem. Biol. 2015, 10, 1791-1796. [CrossRef] [PubMed] 
214. Poirel, L.; Marque, S.; Heritier, C.; Segonds, C.; Chabanon, G.; Nordmann, P. OXA-58, a novel class D \{beta\}-lactamase involved in resistance to carbapenems in Acinetobacter baumannii. Antimicrob. Agents Chemother. 2005, 49, 202-208. [CrossRef] [PubMed]

215. Heritier, C.; Dubouix, A.; Poirel, L.; Marty, N.; Nordmann, P. A nosocomial outbreak of Acinetobacter baumannii isolates expressing the carbapenem-hydrolysing oxacillinase OXA-58. J. Antimicrob. Chemother. 2005, 55, 115-118. [CrossRef] [PubMed]

216. Marque, S.; Poirel, L.; Heritier, C.; Brisse, S.; Blasco, M.D.; Filip, R.; Coman, G.; Naas, T.; Nordmann, P. Regional occurrence of plasmid-mediated carbapenem-hydrolyzing oxacillinase OXA-58 in Acinetobacter spp. in Europe. J. Clin. Microbiol. 2005, 43, 4885-4888. [CrossRef]

217. Matos, A.P.; Cayo, R.; Almeida, L.G.P.; Streling, A.P.; Nodari, C.S.; Martins, W.; Narciso, A.C.; Silva, R.M.; Vasconcelos, A.T.R.; Gales, A.C. Genetic characterization of plasmid-borne blaOXA-58 in distinct Acinetobacter species. mSphere 2019, 4, e00376-19. [CrossRef]

218. Bertini, A.; Poirel, L.; Bernabeu, S.; Fortini, D.; Villa, L.; Nordmann, P.; Carattoli, A. Multicopy blaOXA-58 gene as a source of high-level resistance to carbapenems in Acinetobacter baumannii. Antimicrob. Agents Chemother. 2007, 51, 2324-2328. [CrossRef]

219. Reams, A.B.; Roth, J.R. Mechanisms of gene duplication and amplification. Cold Spring Harb. Perspect. Biol. 2015, 7, a016592. [CrossRef]

220. Peterson, B.C.; Rownd, R.H. Drug resistance gene amplification of plasmid NR1 derivatives with various amounts of resistance determinant DNA. J. Bacteriol. 1985, 161, 1042-1048. [CrossRef]

221. Tolmasky, M.E.; Chamorro, R.M.; Crosa, J.H.; Marini, P.M. Transposon-mediated amikacin resistance in Klebsiella pneumoniae. Antimicrob. Agents Chemother. 1988, 32, 1416-1420. [CrossRef]

222. Peterson, B.C.; Rownd, R.H. Recombination sites in plasmid drug resistance gene amplification. J. Bacteriol. 1985, 164, 1359-1361. [CrossRef]

223. Schechter, L.M.; Creely, D.P.; Garner, C.D.; Shortridge, D.; Nguyen, H.; Chen, L.; Hanson, B.M.; Sodergren, E.; Weinstock, G.M.; Dunne, W.M., Jr.; et al. Extensive gene amplification as a mechanism for piperacillin-tazobactam resistance in Escherichia coli. mBio 2018, 9, e00583-18. [CrossRef]

224. Higgins, P.G.; Poirel, L.; Lehmann, M.; Nordmann, P.; Seifert, H. OXA-143, a novel carbapenem-hydrolyzing class D beta-lactamase in Acinetobacter baumannii. Antimicrob. Agents Chemother. 2009, 53, 5035-5038. [CrossRef] [PubMed]

225. Levy-Blitchtein, S.; Roca, I.; Plasencia-Rebata, S.; Vicente-Taboada, W.; Velasquez-Pomar, J.; Munoz, L.; Moreno-Morales, J.; Pons, M.J.; Del Valle-Mendoza, J.; Vila, J. Emergence and spread of carbapenem-resistant Acinetobacter baumannii international clones II and III in Lima, Peru. Emerg. Microbes Infect. 2018, 7, 119. [CrossRef] [PubMed]

226. Gionco, B.; Pelayo, J.S.; Venancio, E.J.; Cayo, R.; Gales, A.C.; Carrara-Marroni, F.E. Detection of OXA-231, a new variant of blaOXA-143, in Acinetobacter baumannii from Brazil: A case report. J. Antimicrob. Chemother. 2012, 67, 2531-2532. [CrossRef] [PubMed]

227. Kim, C.K.; Lee, Y.; Lee, H.; Woo, G.J.; Song, W.; Kim, M.N.; Lee, W.G.; Jeong, S.H.; Lee, K.; Chong, Y. Prevalence and diversity of carbapenemases among imipenem-nonsusceptible Acinetobacter isolates in Korea: Emergence of a novel OXA-182. Diagn. Microbiol. Infect. Dis. 2010, 68, 432-438. [CrossRef] [PubMed]

228. Mostachio, A.K.; Levin, A.S.; Rizek, C.; Rossi, F.; Zerbini, J.; Costa, S.F. High prevalence of OXA-143 and alteration of outer membrane proteins in carbapenem-resistant Acinetobacter spp. isolates in Brazil. Int. J. Antimicrob. Agents 2012, 39, 396-401. [CrossRef] [PubMed]

229. Zander, E.; Bonnin, R.A.; Seifert, H.; Higgins, P.G. Characterization of blaOXA-143 variants in Acinetobacter baumannii and Acinetobacter pittii. Antimicrob. Agents Chemother. 2014, 58, 2704-2708. [CrossRef]

230. Girlich, D.; Damaceno, Q.S.; Oliveira, A.C.; Nordmann, P. OXA-253, a variant of the carbapenem-hydrolyzing class D beta-lactamase OXA-143 in Acinetobacter baumannii. Antimicrob. Agents Chemother. 2014, 58, 2976-2978. [CrossRef]

231. Higgins, P.G.; Perez-Llarena, F.J.; Zander, E.; Fernandez, A.; Bou, G.; Seifert, H. OXA-235, a novel class D beta-lactamase involved in resistance to carbapenems in Acinetobacter baumannii. Antimicrob. Agents Chemother. 2013, 57, 2121-2126. [CrossRef]

232. Boyd, D.A.; Mataseje, L.F.; Pelude, L.; Mitchell, R.; Bryce, E.; Roscoe, D.; Embree, J.; Katz, K.; Kibsey, P.; Lavallee, C.; et al. Results from the Canadian Nosocomial Infection Surveillance Program for detection of 
carbapenemase-producing Acinetobacter spp. in Canadian hospitals, 2010-2016. J. Antimicrob. Chemother. 2019, 74, 315-320. [CrossRef]

233. Buser, G.L.; Cassidy, P.M.; Cunningham, M.C.; Rudin, S.; Hujer, A.M.; Vega, R.; Furuno, J.P.; Marshall, S.H.; Higgins, P.G.; Jacobs, M.R.; et al. Failure to communicate: Transmission of extensively drug-resistant blaOXA-237-containing Acinetobacter baumannii - multiple facilities in Oregon, 2012-2014. Infect. Control. Hosp. Epidemiol. 2017, 38, 1335-1341. [CrossRef] [PubMed]

234. Hujer, A.M.; Higgins, P.G.; Rudin, S.D.; Buser, G.L.; Marshall, S.H.; Xanthopoulou, K.; Seifert, H.; Rojas, L.J.; Domitrovic, T.N.; Cassidy, P.M.; et al. Nosocomial outbreak of extensively drug-resistant Acinetobacter baumannii isolates containing blaOXA-237 carried on a plasmid. Antimicrob. Agents Chemother. 2017, 61, e00797-17. [CrossRef] [PubMed]

235. Palzkill, T. Metallo-beta-lactamase structure and function. Ann. N. Y. Acad. Sci. 2013, 1277, 91-104. [CrossRef] [PubMed]

236. Mojica, M.F.; Bonomo, R.A.; Fast, W. B1-Metallo-beta-Lactamases: Where Do We Stand? Curr. Drug Targets 2016, 17, 1029-1050. [CrossRef]

237. Walsh, T.R.; Toleman, M.A.; Poirel, L.; Nordmann, P. Metallo-beta-lactamases: The quiet before the storm? Clin. Microbiol. Rev. 2005, 18, 306-325. [CrossRef]

238. Lomovskaya, O.; Nelson, K.; Rubio-Aparicio, D.; Tsivkovski, R.; Sun, D.; Dudley, M.N. The impact of intrinsic resistance mechanisms on potency of QPX7728, a new ultra-broad-spectrum beta-lactamase inhibitor of serine and metallo beta-lactamases in Enterobacteriaceae, Pseudomonas aeruginosa, and Acinetobacter baumannii. Antimicrob. Agents Chemother. 2020, AAC.00552-20. [CrossRef]

239. Hamrick, J.C.; Docquier, J.D.; Uehara, T.; Myers, C.L.; Six, D.A.; Chatwin, C.L.; John, K.J.; Vernacchio, S.F.; Cusick, S.M.; Trout, R.E.L.; et al. VNRX-5133 (Taniborbactam), a broad-spectrum inhibitor of serineand metallo-beta-lactamases, restores activity of cefepime in Enterobacterales and Pseudomonas aeruginosa. Antimicrob. Agents Chemother. 2020, 64, e01963-19. [CrossRef]

240. Krajnc, A.; Brem, J.; Hinchliffe, P.; Calvopina, K.; Panduwawala, T.D.; Lang, P.A.; Kamps, J.; Tyrrell, J.M.; Widlake, E.; Saward, B.G.; et al. Bicyclic boronate VNRX-5133 inhibits metallo- and serine-beta-lactamases. J. Med. Chem. 2019, 62, 8544-8556. [CrossRef]

241. Yong, D.; Toleman, M.A.; Giske, C.G.; Cho, H.S.; Sundman, K.; Lee, K.; Walsh, T.R. Characterization of a new metallo-beta-lactamase gene, bla(NDM-1), and a novel erythromycin esterase gene carried on a unique genetic structure in Klebsiella pneumoniae sequence type 14 from India. Antimicrob. Agents Chemother. 2009, 53, 5046-5054. [CrossRef]

242. Khan, A.U.; Maryam, L.; Zarrilli, R. Structure, genetics and worldwide spread of New Delhi metallo-beta-lactamase (NDM): A threat to public health. BMC Microbiol. 2017, 17, 101. [CrossRef]

243. Wu, W.; Feng, Y.; Tang, G.; Qiao, F.; McNally, A.; Zong, Z. NDM metallo-beta-lactamases and their bacterial producers in health care settings. Clin. Microbiol. Rev. 2019, 32, e00115-e00118. [CrossRef] [PubMed]

244. Karthikeyan, K.; Thirunarayan, M.A.; Krishnan, P. Coexistence of blaOXA-23 with blaNDM-1 and armA in clinical isolates of Acinetobacter baumannii from India. J. Antimicrob. Chemother. 2010, 65, 2253-2254. [CrossRef] [PubMed]

245. Adams, M.D.; Pasteran, F.; Traglia, G.M.; Martinez, J.; Huang, F.; Liu, C.; Fernandez, J.S.; Lopez, C.; Gonzalez, L.J.; Albornoz, E.; et al. Distinct mechanisms of dissemination of NDM-1 metallo-beta-lactamase in Acinetobacter species in Argentina. Antimicrob. Agents Chemother. 2020, 64, e00324-20. [CrossRef] [PubMed]

246. Dortet, L.; Poirel, L.; Nordmann, P. Worldwide dissemination of the NDM-type carbapenemases in Gram-negative bacteria. Biomed. Res. Int. 2014, 2014, 249856. [CrossRef]

247. Groundwater, P.W.; Xu, S.; Lai, F.; Varadi, L.; Tan, J.; Perry, J.D.; Hibbs, D.E. New Delhi metallo-beta-lactamase-1: Structure, inhibitors and detection of producers. Future Med. Chem. 2016, 8, 993-1012. [CrossRef]

248. Khalid, S.; Ahmad, N.; Ali, S.M.; Khan, A.U. Outbreak of efficiently transferred carbapenem-resistant blaNDM-producing gram-negative bacilli isolated from neonatal intensive care unit of an indian hospital. Microb Drug Resist. 2020, 26, 284-289. [CrossRef]

249. Singh, A.; Singh, S.; Singh, K.; Pathak, A.; Prasad, K.N. Acinetobacter baumannii strain ASKPNAB1 Subclass B1 Metallo-Beta-Lactamase NDM-5 (blaNDM) Gene, blaNDM-5 Allele, Complete Cds. Available online: https://www.ncbi.nlm.nih.gov/nuccore/MK682761.1 (accessed on 30 April 2020). 
250. Rogers, B.A.; Sidjabat, H.E.; Silvey, A.; Anderson, T.L.; Perera, S.; Li, J.; Paterson, D.L. Treatment options for New Delhi metallo-beta-lactamase-harboring enterobacteriaceae. Microb Drug Resist. 2013, 19, 100-103. [CrossRef]

251. Abdul Rahim, N.; Cheah, S.E.; Johnson, M.D.; Yu, H.; Sidjabat, H.E.; Boyce, J.; Butler, M.S.; Cooper, M.A.; Fu, J.; Paterson, D.L.; et al. Synergistic killing of NDM-producing MDR Klebsiella pneumoniae by two 'old' antibiotics-polymyxin B and chloramphenicol. J. Antimicrob. Chemother. 2015, 70, 2589-2597. [CrossRef]

252. Linciano, P.; Cendron, L.; Gianquinto, E.; Spyrakis, F.; Tondi, D. Ten years with New Delhi metallo-beta-lactamase-1 (NDM-1): From structural insights to inhibitor design. ACS Infect. Dis 2019, 5, 9-34. [CrossRef]

253. Poirel, L.; Bonnin, R.A.; Nordmann, P. Analysis of the resistome of a multidrug-resistant NDM-1-producing Escherichia coli strain by high-throughput genome sequencing. Antimicrob. Agents Chemother. 2011, 55, 4224-4229. [CrossRef]

254. Huang, T.W.; Wang, J.T.; Lauderdale, T.L.; Liao, T.L.; Lai, J.F.; Tan, M.C.; Lin, A.C.; Chen, Y.T.; Tsai, S.F.; Chang, S.C. Complete sequences of two plasmids in a blaNDM-1-positive Klebsiella oxytoca isolate from Taiwan. Antimicrob. Agents Chemother. 2013, 57, 4072-4076. [CrossRef] [PubMed]

255. Wailan, A.M.; Paterson, D.L.; Kennedy, K.; Ingram, P.R.; Bursle, E.; Sidjabat, H.E. Genomic characteristics of NDM-producing Enterobacteriaceae isolates in Australia and their blaNDM genetic contexts. Antimicrob. Agents Chemother. 2016, 60, 136-141. [CrossRef] [PubMed]

256. Toleman, M.A.; Spencer, J.; Jones, L.; Walsh, T.R. blaNDM-1 is a chimera likely constructed in Acinetobacter baumannii. Antimicrob. Agents Chemother. 2012, 56, 2773-2776. [CrossRef]

257. Poirel, L.; Bonnin, R.A.; Boulanger, A.; Schrenzel, J.; Kaase, M.; Nordmann, P. Tn125-related acquisition of blaNDM-like genes in Acinetobacter baumannii. Antimicrob. Agents Chemother. 2012, 56, 1087-1089. [CrossRef] [PubMed]

258. Bontron, S.; Nordmann, P.; Poirel, L. Transposition of Tn125 encoding the NDM-1 carbapenemase in Acinetobacter baumannii. Antimicrob. Agents Chemother. 2016, 60, 7245-7251.

259. Jones, L.S.; Toleman, M.A.; Weeks, J.L.; Howe, R.A.; Walsh, T.R.; Kumarasamy, K.K. Plasmid carriage of blaNDM-1 in clinical Acinetobacter baumannii isolates from India. Antimicrob. Agents Chemother. 2014, 58, 4211-4213. [CrossRef]

260. McGann, P.; Hang, J.; Clifford, R.J.; Yang, Y.; Kwak, Y.I.; Kuschner, R.A.; Lesho, E.P.; Waterman, P.E. Complete sequence of a novel 178-kilobase plasmid carrying bla(NDM-1) in a Providencia stuartii strain isolated in Afghanistan. Antimicrob. Agents Chemother. 2012, 56, 1673-1679. [CrossRef]

261. Sekizuka, T.; Matsui, M.; Yamane, K.; Takeuchi, F.; Ohnishi, M.; Hishinuma, A.; Arakawa, Y.; Kuroda, M. Complete sequencing of the bla(NDM-1)-positive IncA/C plasmid from Escherichia coli ST38 isolate suggests a possible origin from plant pathogens. PLOS ONE 2011, 6, e25334. [CrossRef]

262. Wailan, A.M.; Sartor, A.L.; Zowawi, H.M.; Perry, J.D.; Paterson, D.L.; Sidjabat, H.E. Genetic contexts of blaNDM-1 in patients carrying multiple NDM-producing Strains. Antimicrob. Agents Chemother. 2015, 59, 7405-7410. [CrossRef]

263. Hudson, C.M.; Bent, Z.W.; Meagher, R.J.; Williams, K.P. Resistance determinants and mobile genetic elements of an NDM-1-encoding Klebsiella pneumoniae strain. PLoS ONE 2014, 9, e99209. [CrossRef]

264. Partridge, S.R.; Iredell, J.R. Genetic contexts of blaNDM-1. Antimicrob. Agents Chemother. 2012, 56, 6065-6067. [CrossRef] [PubMed]

265. Martin, P.; Jullien, E.; Courvalin, P. Nucleotide sequence of Acinetobacter baumannii aphA-6 gene: Evolutionary and functional implications of sequence homologies with nucleotide-binding proteins, kinases and other aminoglycoside-modifying enzymes. Mol. Microbiol. 1988, 2, 615-625. [CrossRef] [PubMed]

266. Zhang, H.; Hao, Q. Crystal structure of NDM-1 reveals a common beta-lactam hydrolysis mechanism. FASEB J. 2011, 25, 2574-2582. [CrossRef] [PubMed]

267. King, D.; Strynadka, N. Crystal structure of New Delhi metallo-beta-lactamase reveals molecular basis for antibiotic resistance. Protein Sci. 2011, 20, 1484-1491. [CrossRef] [PubMed]

268. Kim, Y.; Tesar, C.; Mire, J.; Jedrzejczak, R.; Binkowski, A.; Babnigg, G.; Sacchettini, J.; Joachimiak, A. Structure of apo- and monometalated forms of NDM-1-a highly potent carbapenem-hydrolyzing metallo-beta-lactamase. PLOS ONE 2011, 6, e24621. 
269. Lisa, M.N.; Palacios, A.R.; Aitha, M.; Gonzalez, M.M.; Moreno, D.M.; Crowder, M.W.; Bonomo, R.A.; Spencer, J.; Tierney, D.L.; Llarrull, L.I.; et al. A general reaction mechanism for carbapenem hydrolysis by mononuclear and binuclear metallo-beta-lactamases. Nat. Commun. 2017, 8, 538. [CrossRef]

270. Zheng, M.; Xu, D. New Delhi metallo-beta-lactamase I: Substrate binding and catalytic mechanism. J. Phys. Chem. B 2013, 117, 11596-11607. [CrossRef]

271. Kim, Y.; Cunningham, M.A.; Mire, J.; Tesar, C.; Sacchettini, J.; Joachimiak, A. NDM-1, the ultimate promiscuous enzyme: Substrate recognition and catalytic mechanism. FASEB J. 2013, 27, 1917-1927. [CrossRef]

272. Kozlyuk, N.; Monteith, A.J.; Garcia, V.; Damo, S.M.; Skaar, E.P.; Chazin, W.J. S100 Proteins in the Innate Immune Response to Pathogens. Methods Mol. Biol. 2019, 1929, 275-290.

273. Diaz-Ochoa, V.E.; Jellbauer, S.; Klaus, S.; Raffatellu, M. Transition metal ions at the crossroads of mucosal immunity and microbial pathogenesis. Front. Cell Infect. Microbiol. 2014, 4, 2. [CrossRef]

274. Corbin, B.D.; Seeley, E.H.; Raab, A.; Feldmann, J.; Miller, M.R.; Torres, V.J.; Anderson, K.L.; Dattilo, B.M.; Dunman, P.M.; Gerads, R.; et al. Metal chelation and inhibition of bacterial growth in tissue abscesses. Science 2008, 319, 962-965. [CrossRef] [PubMed]

275. Gonzalez, J.M.; Meini, M.R.; Tomatis, P.E.; Medrano Martin, F.J.; Cricco, J.A.; Vila, A.J. Metallo-beta-lactamases withstand low $\mathrm{Zn}(\mathrm{II})$ conditions by tuning metal-ligand interactions. Nat. Chem. Biol. 2012, 8, 698-700. [CrossRef] [PubMed]

276. Gonzalez, L.J.; Bahr, G.; Nakashige, T.G.; Nolan, E.M.; Bonomo, R.A.; Vila, A.J. Membrane anchoring stabilizes and favors secretion of New Delhi metallo-beta-lactamase. Nat. Chem. Biol. 2016, 12, 516-522. [CrossRef] [PubMed]

277. Lopez, C.; Ayala, J.A.; Bonomo, R.A.; Gonzalez, L.J.; Vila, A.J. Protein determinants of dissemination and host specificity of metallo-beta-lactamases. Nat. Commun. 2019, 10, 3617. [CrossRef]

278. Lauretti, L.; Riccio, M.L.; Mazzariol, A.; Cornaglia, G.; Amicosante, G.; Fontana, R.; Rossolini, G.M. Cloning and characterization of blaVIM, a new integron-borne metallo-beta-lactamase gene from a Pseudomonas aeruginosa clinical isolate. Antimicrob. Agents Chemother. 1999, 43, 1584-1590. [CrossRef] [PubMed]

279. Poirel, L.; Naas, T.; Nicolas, D.; Collet, L.; Bellais, S.; Cavallo, J.D.; Nordmann, P. Characterization of VIM-2, a carbapenem-hydrolyzing metallo-beta-lactamase and its plasmid- and integron-borne gene from a Pseudomonas aeruginosa clinical isolate in France. Antimicrob. Agents Chemother. 2000, 44, 891-897. [CrossRef]

280. Kazmierczak, K.M.; Rabine, S.; Hackel, M.; McLaughlin, R.E.; Biedenbach, D.J.; Bouchillon, S.K.; Sahm, D.F.; Bradford, P.A. Multiyear, multinational survey of the incidence and global distribution of metallo-beta-lactamase-producing Enterobacteriaceae and Pseudomonas aeruginosa. Antimicrob. Agents Chemother. 2016, 60, 1067-1078. [CrossRef]

281. Matsumura, Y.; Peirano, G.; Devinney, R.; Bradford, P.A.; Motyl, M.R.; Adams, M.D.; Chen, L.; Kreiswirth, B.; Pitout, J.D.D. Genomic epidemiology of global VIM-producing Enterobacteriaceae. J. Antimicrob. Chemother. 2017, 72, 2249-2258. [CrossRef]

282. Lee, K.; Lee, W.G.; Uh, Y.; Ha, G.Y.; Cho, J.; Chong, Y.; Korean Nationwide Surveillance of Antimicrobial Resistance Group. VIM- and IMP-type metallo-beta-lactamase-producing Pseudomonas spp. and Acinetobacter spp. in Korean hospitals. Emerg. Infect. Dis. 2003, 9, 868-871. [CrossRef]

283. Yum, J.H.; Yi, K.; Lee, H.; Yong, D.; Lee, K.; Kim, J.M.; Rossolini, G.M.; Chong, Y. Molecular characterization of metallo-beta-lactamase-producing Acinetobacter baumannii and Acinetobacter genomospecies 3 from Korea: Identification of two new integrons carrying the bla(VIM-2) gene cassettes. J. Antimicrob. Chemother. 2002, 49, 837-840. [CrossRef]

284. Tsakris, A.; Ikonomidis, A.; Pournaras, S.; Tzouvelekis, L.S.; Sofianou, D.; Legakis, N.J.; Maniatis, A.N. VIM-1 metallo-beta-lactamase in Acinetobacter baumannii. Emerg. Infect. Dis. 2006, 12, 981-983. [CrossRef] [PubMed]

285. El-Ageery, S.M.; Al-Hazmi, S.S. Microbiological and molecular detection of VIM-1 metallo beta lactamase-producing Acinetobacter baumannii. Eur. Rev. Med. Pharmacol. Sci. 2014, 18, 965-970. [PubMed]

286. Beigverdi, R.; Sattari-Maraji, A.; Emaneini, M.; Jabalameli, F. Status of carbapenem-resistant Acinetobacter baumannii harboring carbapenemase: First systematic review and meta-analysis from Iran. Infect. Genet. Evol. 2019, 73, 433-443. [CrossRef]

287. Davoodi, S.; Boroumand, M.A.; Sepehriseresht, S.; Pourgholi, L. Detection of VIM- and IMP-type metallo-beta-lactamase genes in Acinetobacter baumannii isolates from patients in two hospitals in Tehran. Iran. J. Biotechnol. 2015, 13, 63-67. [CrossRef] [PubMed] 
288. Rezaei, A.; Fazeli, H.; Halaji, M.; Moghadampour, M.; Faghri, J. Prevalence of metallo-beta-lactamase producing Acinetobacter baumannii isolated from intensive care unit in tertiary care hospitals. Ann. Ig. 2018, 30, 330-336. [PubMed]

289. Lee, M.F.; Peng, C.F.; Hsu, H.J.; Chen, Y.H. Molecular characterisation of the metallo-beta-lactamase genes in imipenem-resistant Gram-negative bacteria from a university hospital in southern Taiwan. Int. J. Antimicrob. Agents 2008, 32, 475-480. [CrossRef]

290. Peymani, A.; Nahaei, M.R.; Farajnia, S.; Hasani, A.; Mirsalehian, A.; Sohrabi, N.; Abbasi, L. High prevalence of metallo-beta-lactamase-producing Acinetobacter baumannii in a teaching hospital in Tabriz, Iran. Jpn. J. Infect. Dis. 2011, 64, 69-71.

291. El-Badawy, M.F.; Abdelwahab, S.F.; Alghamdi, S.A.; Shohayeb, M.M. Characterization of phenotypic and genotypic traits of carbapenem-resistant Acinetobacter baumannii clinical isolates recovered from a tertiary care hospital in Taif, Saudi Arabia. Infect. Drug Resist. 2019, 12, 3113-3124. [CrossRef]

292. Benmahmod, A.B.; Said, H.S.; Ibrahim, R.H. Prevalence and mechanisms of carbapenem resistance among Acinetobacter baumannii clinical isolates in Egypt. Microb. Drug Resist. 2019, 25, 480-488. [CrossRef]

293. Azimi, L.; Talebi, M.; Pourshafie, M.R.; Owlia, P.; Rastegar Lari, A. Characterization of carbapenemases in extensively drug resistant Acinetobacter baumannii in a burn care center in Iran. Int. J. Mol Cell Med. 2015, 4, $46-53$.

294. AlAmri, A.M.; AlQurayan, A.M.; Sebastian, T.; AlNimr, A.M. Molecular surveillance of multidrug-resistant Acinetobacter baumannii. Curr. Microbiol. 2020, 77, 335-342. [CrossRef] [PubMed]

295. Girija, S.A.; Jayaseelan, V.P.; Arumugam, P. Prevalence of VIM- and GIM-producing Acinetobacter baumannii from patients with severe urinary tract infection. Acta Microbiol. Immunol. Hung. 2018, 65, 539-550. [CrossRef] [PubMed]

296. Amin, M.; Navidifar, T.; Saleh Shooshtari, F.; Goodarzi, H. Association of the genes encoding metallo-beta-lactamase with the presence of integrons among multidrug-resistant clinical isolates of Acinetobacter baumannii. Infect. Drug Resist. 2019, 12, 1171-1180. [CrossRef]

297. Watanabe, M.; Iyobe, S.; Inoue, M.; Mitsuhashi, S. Transferable imipenem resistance in Pseudomonas aeruginosa. Antimicrob. Agents Chemother. 1991, 35, 147-151. [CrossRef] [PubMed]

298. Osano, E.; Arakawa, Y.; Wacharotayankun, R.; Ohta, M.; Horii, T.; Ito, H.; Yoshimura, F.; Kato, N. Molecular characterization of an enterobacterial metallo beta-lactamase found in a clinical isolate of Serratia marcescens that shows imipenem resistance. Antimicrob. Agents Chemother. 1994, 38, 71-78. [CrossRef] [PubMed]

299. Arakawa, Y.; Murakami, M.; Suzuki, K.; Ito, H.; Wacharotayankun, R.; Ohsuka, S.; Kato, N.; Ohta, M. A novel integron-like element carrying the metallo-beta-lactamase gene blaIMP. Antimicrob. Agents Chemother. 1995, 39, 1612-1615. [CrossRef] [PubMed]

300. Ito, H.; Arakawa, Y.; Ohsuka, S.; Wacharotayankun, R.; Kato, N.; Ohta, M. Plasmid-mediated dissemination of the metallo-beta-lactamase gene blaIMP among clinically isolated strains of Serratia marcescens. Antimicrob. Agents Chemother. 1995, 39, 824-829. [CrossRef]

301. Hirakata, Y.; Izumikawa, K.; Yamaguchi, T.; Takemura, H.; Tanaka, H.; Yoshida, R.; Matsuda, J.; Nakano, M.; Tomono, K.; Maesaki, S.; et al. Rapid detection and evaluation of clinical characteristics of emerging multiple-drug-resistant gram-negative rods carrying the metallo-beta-lactamase gene blaIMP. Antimicrob. Agents Chemother. 1998, 42, 2006-2011. [CrossRef] [PubMed]

302. Koh, T.H.; Babini, G.S.; Woodford, N.; Sng, L.H.; Hall, L.M.; Livermore, D.M. Carbapenem-hydrolysing IMP-1 beta-lactamase in Klebsiella pneumoniae from Singapore. Lancet 1999, 353, 2162. [CrossRef]

303. Senda, K.; Arakawa, Y.; Nakashima, K.; Ito, H.; Ichiyama, S.; Shimokata, K.; Kato, N.; Ohta, M. Multifocal outbreaks of metallo-beta-lactamase-producing Pseudomonas aeruginosa resistant to broad-spectrum beta-lactams, including carbapenems. Antimicrob. Agents Chemother. 1996, 40, 349-353. [CrossRef]

304. Riccio, M.L.; Franceschini, N.; Boschi, L.; Caravelli, B.; Cornaglia, G.; Fontana, R.; Amicosante, G.; Rossolini, G.M. Characterization of the metallo-beta-lactamase determinant of Acinetobacter baumannii AC-54/97 reveals the existence of bla(IMP) allelic variants carried by gene cassettes of different phylogeny. Antimicrob. Agents Chemother. 2000, 44, 1229-1235. [CrossRef] [PubMed]

305. Cornaglia, G.; Riccio, M.L.; Mazzariol, A.; Lauretti, L.; Fontana, R.; Rossolini, G.M. Appearance of IMP-1 metallo-beta-lactamase in Europe. Lancet 1999, 353, 899-900. [CrossRef] 
306. Ramirez, M.S.; Parenteau, T.R.; Centron, D.; Tolmasky, M.E. Functional characterization of Tn1331 gene cassettes. J. Antimicrob. Chemother. 2008, 62, 669-673. [CrossRef] [PubMed]

307. Sarno, R.; McGillivary, G.; Sherratt, D.J.; Actis, L.A.; Tolmasky, M.E. Complete nucleotide sequence of Klebsiella pneumoniae multiresistance plasmid pJHCMW1. Antimicrob. Agents Chemother. 2002, 46, 3422-3427. [CrossRef]

308. Tolmasky, M.E.; Crosa, J.H. Tn1331, a novel multiresistance transposon encoding resistance to amikacin and ampicillin in Klebsiella pneumoniae. Antimicrob. Agents Chemother. 1987, 31, 1955-1960. [CrossRef]

309. Casin, I.; Hanau-Bercot, B.; Podglajen, I.; Vahaboglu, H.; Collatz, E. Salmonella enterica serovar Typhimurium bla(PER-1)-carrying plasmid pSTI1 encodes an extended-spectrum aminoglycoside 6 - $N$-acetyltransferase of type Ib. Antimicrob. Agents Chemother. 2003, 47, 697-703. [CrossRef]

310. Dery, K.J.; Soballe, B.; Witherspoon, M.S.; Bui, D.; Koch, R.; Sherratt, D.J.; Tolmasky, M.E. The aminoglycoside 6 '-N-acetyltransferase type Ib encoded by Tn1331 is evenly distributed within the cell's cytoplasm. Antimicrob. Agents Chemother. 2003, 47, 2897-2902. [CrossRef]

311. Nobuta, K.; Tolmasky, M.E.; Crosa, L.M.; Crosa, J.H. Sequencing and expression of the 6 '-N-acetyltransferase gene of transposon Tn1331 from Klebsiella pneumoniae. J. Bacteriol. 1988, 170, 3769-3773. [CrossRef]

312. Da Silva, G.J.; Correia, M.; Vital, C.; Ribeiro, G.; Sousa, J.C.; Leitao, R.; Peixe, L.; Duarte, A. Molecular characterization of bla(IMP-5), a new integron-borne metallo-beta-lactamase gene from an Acinetobacter baumannii nosocomial isolate in Portugal. FEMS Microbiol. Lett. 2002, 215, 33-39.

313. Iyobe, S.; Kusadokoro, H.; Ozaki, J.; Matsumura, N.; Minami, S.; Haruta, S.; Sawai, T.; O’Hara, K. Amino acid substitutions in a variant of IMP-1 metallo-beta-lactamase. Antimicrob. Agents Chemother. 2000, 44, 2023-2027. [CrossRef]

314. Chu, Y.W.; Afzal-Shah, M.; Houang, E.T.; Palepou, M.I.; Lyon, D.J.; Woodford, N.; Livermore, D.M. IMP-4, a novel metallo-beta-lactamase from nosocomial Acinetobacter spp. collected in Hong Kong between 1994 and 1998. Antimicrob. Agents Chemother. 2001, 45, 710-714. [CrossRef] [PubMed]

315. Hawkey, P.M.; Xiong, J.; Ye, H.; Li, H.; M'Zali, F.H. Occurrence of a new metallo-beta-lactamase IMP-4 carried on a conjugative plasmid in Citrobacter youngae from the People's Republic of China. FEMS Microbiol. Lett. 2001, 194, 53-57. [PubMed]

316. Koh, T.H.; Sng, L.H.; Wang, G.C.; Hsu, L.Y.; Zhao, Y. IMP-4 and OXA beta-lactamases in Acinetobacter baumannii from Singapore. J. Antimicrob. Chemother. 2007, 59, 627-632. [CrossRef] [PubMed]

317. Partridge, S.R.; Ginn, A.N.; Paulsen, I.T.; Iredell, J.R. pEl1573 Carrying blaIMP-4, from Sydney, Australia, is closely related to other IncL/M plasmids. Antimicrob. Agents Chemother. 2012, 56, 6029-6032. [CrossRef]

318. Sidjabat, H.E.; Heney, C.; George, N.M.; Nimmo, G.R.; Paterson, D.L. Interspecies transfer of blaIMP-4 in a patient with prolonged colonization by IMP-4-producing Enterobacteriaceae. J. Clin. Microbiol. 2014, 52, 3816-3818. [CrossRef]

319. Peleg, A.Y.; Franklin, C.; Walters, L.J.; Bell, J.M.; Spelman, D.W. OXA-58 and IMP-4 carbapenem-hydrolyzing beta-lactamases in an Acinetobacter junii blood culture isolate from Australia. Antimicrob. Agents Chemother. 2006, 50, 399-400. [CrossRef]

320. Azizi, O.; Shakibaie, M.R.; Badmasti, F.; Modarresi, F.; Ramazanzadeh, R.; Mansouri, S.; Shahcheraghi, F. Class 1 integrons in non-clonal multidrug-resistant Acinetobacter baumannii from Iran, description of the new blaIMP-55 allele in In1243. J. Med. Microbiol. 2016, 65, 928-936. [CrossRef]

321. Yigit, H.; Queenan, A.M.; Anderson, G.J.; Domenech-Sanchez, A.; Biddle, J.W.; Steward, C.D.; Alberti, S.; Bush, K.; Tenover, F.C. Novel carbapenem-hydrolyzing beta-lactamase, KPC-1, from a carbapenem-resistant strain of Klebsiella pneumoniae. Antimicrob. Agents Chemother. 2001, 45, 1151-1161. [CrossRef]

322. Miriagou, V.; Tzouvelekis, L.S.; Rossiter, S.; Tzelepi, E.; Angulo, F.J.; Whichard, J.M. Imipenem resistance in a Salmonella clinical strain due to plasmid-mediated class A carbapenemase KPC-2. Antimicrob. Agents Chemother. 2003, 47, 1297-1300. [CrossRef]

323. Smith Moland, E.; Hanson, N.D.; Herrera, V.L.; Black, J.A.; Lockhart, T.J.; Hossain, A.; Johnson, J.A.; Goering, R.V.; Thomson, K.S. Plasmid-mediated, carbapenem-hydrolysing beta-lactamase, KPC-2, in Klebsiella pneumoniae isolates. J. Antimicrob. Chemother. 2003, 51, 711-714. [CrossRef]

324. Woodford, N.; Tierno, P.M., Jr.; Young, K.; Tysall, L.; Palepou, M.F.; Ward, E.; Painter, R.E.; Suber, D.F.; Shungu, D.; Silver, L.L.; et al. Outbreak of Klebsiella pneumoniae producing a new carbapenem-hydrolyzing class A beta-lactamase, KPC-3, in a New York Medical Center. Antimicrob. Agents Chemother. 2004, 48, 4793-4799. [CrossRef] [PubMed] 
325. Abdallah, M.; Olafisoye, O.; Cortes, C.; Urban, C.; Landman, D.; Ghitan, M.; Collins, B.; Bratu, S.; Quale, J. Rise and fall of KPC-producing Klebsiella pneumoniae in New York City. J. Antimicrob. Chemother. 2016, 71, 2945-2948. [CrossRef] [PubMed]

326. Kazmierczak, K.M.; Biedenbach, D.J.; Hackel, M.; Rabine, S.; de Jonge, B.L.; Bouchillon, S.K.; Sahm, D.F.; Bradford, P.A. Global dissemination of blaKPC into bacterial species beyond Klebsiella pneumoniae and in vitro susceptibility to ceftazidime-avibactam and aztreonam-avibactam. Antimicrob. Agents Chemother. 2016, 60, 4490-4500. [CrossRef] [PubMed]

327. Naas, T.; Nordmann, P.; Vedel, G.; Poyart, C. Plasmid-mediated carbapenem-hydrolyzing beta-lactamase KPC in a Klebsiella pneumoniae isolate from France. Antimicrob. Agents Chemother. 2005, 49, 4423-4424. [CrossRef] [PubMed]

328. Munoz-Price, L.S.; Poirel, L.; Bonomo, R.A.; Schwaber, M.J.; Daikos, G.L.; Cormican, M.; Cornaglia, G.; Garau, J.; Gniadkowski, M.; Hayden, M.K.; et al. Clinical epidemiology of the global expansion of Klebsiella pneumoniae carbapenemases. Lancet Infect. Dis. 2013, 13, 785-796. [CrossRef]

329. Ramirez, M.S.; Xie, G.; Marshall, S.H.; Hujer, K.M.; Chain, P.S.; Bonomo, R.A.; Tolmasky, M.E. Multidrug-resistant (MDR) Klebsiella pneumoniae clinical isolates: A zone of high heterogeneity (HHZ) as a tool for epidemiological studies. Clin. Microbiol. Infect. 2012, 18, E254-E258. [CrossRef] [PubMed]

330. Ramirez, M.S.; Xie, G.; Traglia, G.M.; Johnson, S.L.; Davenport, K.W.; van Duin, D.; Ramazani, A.; Perez, F.; Jacobs, M.R.; Sherratt, D.J.; et al. Whole-genome comparative analysis of two carbapenem-resistant ST-258 Klebsiella pneumoniae strains Isolated during a North-eastern Ohio outbreak: Differences within the high heterogeneity zones. Genome Biol. Evol. 2016, 8, 2036-2043. [CrossRef] [PubMed]

331. Park, S.O.; Liu, J.; Furuya, E.Y.; Larson, E.L. Carbapenem-resistant Klebsiella pneumoniae infection in three New York City hospitals trended downwards from 2006 to 2014. Open Forum Infect. Dis 2016, 3, ofw222. [CrossRef]

332. Naas, T.; Cuzon, G.; Villegas, M.V.; Lartigue, M.F.; Quinn, J.P.; Nordmann, P. Genetic structures at the origin of acquisition of the beta-lactamase blaKPC gene. Antimicrob. Agents Chemother. 2008, 52, 1257-1263. [CrossRef]

333. Leavitt, A.; Chmelnitsky, I.; Ofek, I.; Carmeli, Y.; Navon-Venezia, S. Plasmid pKpQIL encoding KPC-3 and TEM-1 confers carbapenem resistance in an extremely drug-resistant epidemic Klebsiella pneumoniae strain. J. Antimicrob. Chemother. 2010, 65, 243-248. [CrossRef]

334. Gootz, T.D.; Lescoe, M.K.; Dib-Hajj, F.; Dougherty, B.A.; He, W.; Della-Latta, P.; Huard, R.C. Genetic organization of transposase regions surrounding blaKPC carbapenemase genes on plasmids from Klebsiella strains isolated in a New York City hospital. Antimicrob. Agents Chemother. 2009, 53, 1998-2004. [CrossRef] [PubMed]

335. Chen, L.; Chavda, K.D.; Al Laham, N.; Melano, R.G.; Jacobs, M.R.; Bonomo, R.A.; Kreiswirth, B.N. Complete nucleotide sequence of a blaKPC-harboring IncI2 plasmid and its dissemination in New Jersey and New York hospitals. Antimicrob. Agents Chemother. 2013, 57, 5019-5025. [CrossRef] [PubMed]

336. Ho, P.L.; Cheung, Y.Y.; Lo, W.U.; Li, Z.; Chow, K.H.; Lin, C.H.; Chan, J.F.; Cheng, V.C. Molecular characterization of an atypical IncX3 plasmid pKPC-NY79 carrying blaKPC-2 in a Klebsiella pneumoniae. Curr. Microbiol. 2013, 67, 493-498. [CrossRef] [PubMed]

337. Partridge, S.R. Tn4401 carrying blaKPC is inserted within another insertion in pKpQIL and related plasmids. J. Clin. Microbiol. 2014, 52, 4448-4449. [CrossRef]

338. Rice, L.B.; Carias, L.L.; Hutton, R.A.; Rudin, S.D.; Endimiani, A.; Bonomo, R.A. The KQ element, a complex genetic region conferring transferable resistance to carbapenems, aminoglycosides, and fluoroquinolones in Klebsiella pneumoniae. Antimicrob. Agents Chemother. 2008, 52, 3427-3429. [CrossRef]

339. Souza, R.C.; Dabul, A.N.G.; Boralli, C.; Zuvanov, L.; Camargo, I. Dissemination of blaKPC-2 in an NTEKPC by an IncX5 plasmid. Plasmid 2019, 106, 102446. [CrossRef]

340. Chen, L.; Mathema, B.; Chavda, K.D.; DeLeo, F.R.; Bonomo, R.A.; Kreiswirth, B.N. Carbapenemase-producing Klebsiella pneumoniae: Molecular and genetic decoding. Trends Microbiol. 2014, 22, 686-696. [CrossRef]

341. Wang, L.; Fang, H.; Feng, J.; Yin, Z.; Xie, X.; Zhu, X.; Wang, J.; Chen, W.; Yang, R.; Du, H.; et al. Complete sequences of KPC-2-encoding plasmid p628-KPC and CTX-M-55-encoding p628-CTXM coexisted in Klebsiella pneumoniae. Front. Microbiol. 2015, 6, 838. [CrossRef]

342. Azimi, L.; Talebi, M.; Khodaei, F.; Najafi, M.; Lari, A.R. Comparison of multiple-locus variable-number tandem-repeat analysis with pulsed-field gel electrophoresis typing of carbapenemases producing Acinetobacter baumannii isolated from burn patients. Burns 2016, 42, 441-445. [CrossRef] 
343. Lima, W.G.; Silva Alves, G.C.; Sanches, C.; Antunes Fernandes, S.O.; de Paiva, M.C. Carbapenem-resistant Acinetobacter baumannii in patients with burn injury: A systematic review and meta-analysis. Burns 2019, 45, 1495-1508. [CrossRef]

344. Ribeiro, P.C.; Monteiro, A.S.; Marques, S.G.; Monteiro, S.G.; Monteiro-Neto, V.; Coqueiro, M.M.; Marques, A.C.; de Jesus Gomes Turri, R.; Santos, S.G.; Bomfim, M.R. Phenotypic and molecular detection of the blaKPC gene in clinical isolates from inpatients at hospitals in Sao Luis, MA, Brazil. BMC Infect. Dis. 2016, 16, 737. [CrossRef] [PubMed]

345. Robledo, I.E.; Aquino, E.E.; Sante, M.I.; Santana, J.L.; Otero, D.M.; Leon, C.F.; Vazquez, G.J. Detection of KPC in Acinetobacter spp. in Puerto Rico. Antimicrob. Agents Chemother. 2010, 54, 1354-1357. [CrossRef] [PubMed]

346. Ju, L.C.; Cheng, Z.; Fast, W.; Bonomo, R.A.; Crowder, M.W. The continuing challenge of metallo-beta-lactamase inhibition: Mechanism matters. Trends Pharmacol. Sci. 2018, 39, 635-647. [CrossRef] [PubMed]

347. Tolmasky, M.E. Strategies to prolong the useful life of existing antibiotics and help overcoming the antibiotic resistance crisis. In Frontiers in Clinical Drug Research-Anti Infectives; Atta-ur-Rhaman, Ed.; Bentham Books: Sharjah, UAE, 2017; Volume 1, pp. 1-27.

348. Papp-Wallace, K.M.; Bonomo, R.A. New beta-lactamase inhibitors in the clinic. Infect. Dis. Clin. North. Am. 2016, 30, 441-464. [CrossRef] [PubMed]

349. Noval, M.; Banoub, M.; Claeys, K.C.; Heil, E. The battle is on: New beta-lactams for the treatment of multidrug-resistant gram-negative organisms. Curr. Infect. Dis. Rep. 2020, 22, 1. [CrossRef] [PubMed]

350. Carpenter, J.; Neidig, N.; Campbell, A.; Thornsberry, T.; Truex, T.; Fortney, T.; Zhang, Y.; Bush, K. Activity of imipenem/relebactam against carbapenemase-producing Enterobacteriaceae with high colistin resistance. J. Antimicrob. Chemother. 2019, 74, 3260-3263. [CrossRef]

351. Haidar, G.; Clancy, C.J.; Shields, R.K.; Hao, B.; Cheng, S.; Nguyen, M.H. Mutations in blaKPC-3 that confer ceftazidime-avibactam resistance encode novel KPC-3 variants that function as extended-spectrum beta-lactamases. Antimicrob. Agents Chemother. 2017, 61, e02534-16. [CrossRef]

352. Porreca, A.M.; Sullivan, K.V.; Gallagher, J.C. The epidemiology, evolution, and treatment of KPC-producing organisms. Curr. Infect. Dis. Rep. 2018, 20, 13. [CrossRef]

353. Doi, Y.; Murray, G.L.; Peleg, A.Y. Acinetobacter baumannii: Evolution of antimicrobial resistance-treatment options. Semin. Respir. Crit. Care Med. 2015, 36, 85-98.

354. Traglia, G.M.; Chua, K.; Centron, D.; Tolmasky, M.E.; Ramirez, M.S. Whole-genome sequence analysis of the naturally competent Acinetobacter baumannii clinical isolate A118. Genome Biol. Evol. 2014, 6, 2235-2239. [CrossRef]

355. Imperi, F.; Antunes, L.C.; Blom, J.; Villa, L.; Iacono, M.; Visca, P.; Carattoli, A. The genomics of Acinetobacter baumannii: Insights into genome plasticity, antimicrobial resistance and pathogenicity. IUBMB Life 2011, 63, 1068-1074. [CrossRef] [PubMed]

356. Traglia, G.M.; Place, K.; Dotto, C.; Fernandez, J.S.; Montana, S.; Bahiense, C.D.S.; Soler-Bistue, A.; Iriarte, A.; Perez, F.; Tolmasky, M.E.; et al. Interspecies DNA acquisition by a naturally competent Acinetobacter baumannii strain. Int. J. Antimicrob. Agents 2019, 53, 483-490. [CrossRef] [PubMed]

(C) 2020 by the authors. Licensee MDPI, Basel, Switzerland. This article is an open access article distributed under the terms and conditions of the Creative Commons Attribution (CC BY) license (http://creativecommons.org/licenses/by/4.0/). 